\title{
Belowground cycling of carbon in forests and pastures of Eastern Amazonia
}

\author{
Susan E. Trumbore, ${ }^{1}$ Eric A. Davidson, ${ }^{2}$ Plínio Barbosa de Camargo, 3 \\ Daniel C. Nepstad, ${ }^{2}$ and Luiz Antonio Martinelli ${ }^{3}$
}

\begin{abstract}
Forests in seasonally dry areas of eastern Amazonia near Paragominas, Pará, Brazil, maintain an evergreen forest canopy through an extended dry season by taking up soil water through deep $(>1 \mathrm{~m})$ roots. Belowground allocation of $\mathrm{C}$ in these deep-rooting forests is very large $\left(1900 \mathrm{~g} \mathrm{C} \mathrm{m}^{-2} \mathrm{yr}^{-1}\right)$ relative to litterfall $\left(460 \mathrm{~g} \mathrm{C} \mathrm{m}^{-2} \mathrm{yr}^{-1}\right)$. The presence of live roots drives an active carbon cycle deeper than $1 \mathrm{~m}$ in the soil. Although bulk $\mathrm{C}$ concentrations and ${ }^{14} \mathrm{C}$ contents of soil organic matter at $>1-\mathrm{m}$ depths are low, estimates of turnover from fine-root inputs, $\mathrm{CO}_{2}$ production, and the ${ }^{14} \mathrm{C}$ content of $\mathrm{CO}_{2}$ produced at depth show that up to $15 \%$ of the carbon inventory in the deep soil has turnover times of decades or less. Thus the amount of fastcycling soil carbon between land 8-m depths $\left(2-3 \mathrm{~kg} \mathrm{C} \mathrm{m}^{-2}\right.$, out of $\left.17-18 \mathrm{~kg} \mathrm{C} \mathrm{m}^{-2}\right)$ is significant compared to the amount present in the upper meter of soil $\left(3-4 \mathrm{~kg} \mathrm{C} \mathrm{m}^{-2}\right.$ out of $\left.10-11 \mathrm{~kg} \mathrm{C} \mathrm{m}^{-2}\right)$. A model of belowground carbon cycling derived from measurements of carbon stocks and fluxes, and constrained using carbon isotopes, is used to predict $C$ fluxes associated with conversion of deep-rooting forests to pasture and subsequent pasture management. The relative proportions and turnover times of active (including detrital plant material; 1-3 year turnover), slow (decadal and shorter turnover), and passive (centennial to millennial turnover) soil organic matter pools are determined by depth for the forest soil, using constraints from measurements of $\mathrm{C}$ stocks, fluxes, and isotopic content. Reduced carbon inputs to the soil in degraded pastures, which are less productive than the forests they replace, lead to a reduction in soil carbon inventory and $\Delta^{14} \mathrm{C}$, in accord with observations. Managed pastures, which have been fertilized with phosphorous and planted with more productive grasses, show increases in $\mathrm{C}$ and ${ }^{14} \mathrm{C}$ over forest values. Carbon inventory increases in the upper meter of managed pasture soils are partially offset by predicted carbon losses due to death and decomposition of fine forest roots at depths $>1 \mathrm{~m}$ in the soil. The major adjustments in soil carbon inventory in response to land management changes occur within the first decade after conversion. Carbon isotopes are shown to be more sensitive indicators of recent accumulation or loss of soil organic matter than direct measurement of soil $\mathrm{C}$ inventories.
\end{abstract}

\section{Introduction}

The amount of carbon stored in the upper meter of tropical soils is estimated to be $13-17 \%$ of global soil carbon storage [Schlesinger, 1977; Post et al., 1982; Sombroek et al., 1993]. Several recent studies have demonstrated that carbon in tropical forest soils has rapid turnover rates, with $>60 \%$ of the carbon in the upper $20 \mathrm{~cm}$ turning over on timescales of 25 years or less in Andisols from Hawaii and Costa Rica [Veldkamp, 1994; Townsend et al., 1995] and Oxisols in Brazil [Chone et al., 1991; Trumbore, 1993]. Ecosystem models which include soil carbon and nitrogen cycling predict carbon turnover times of less than a

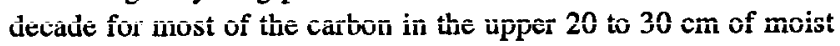
tropical forest soils [Potter et al., 1993; Schimel et al., 1994].

Short residence times for a large portion of the soil organic

\footnotetext{
${ }^{2}$ Department of Earth System Science, University of California, Irvine.

${ }^{2}$ Woods Hole Research Center, Woods Hold, Massachusetts.

${ }^{3}$ Centro de Energia Nuclear na Agricultura, Piracicaba, São Paulo, Brazil.
}

Copyright 1995 by the American Geophysical Union.

Paper number 95GB02148. 0886-6236/95/95GB-02148 $\$ 10.00$ matter (SOM) in tropical soils imply the potential for rapid and large changes in soil carbon inventory in response to changes in soil carbon inputs accompanying disturbance, such as deforestation and replacement of forest with pasture vegetation. Studies of change in carbon inventory in soils following deforestation have shown both increases [Lugo and Brown, 1993; Fisher et al., 1994] and decreases [Detweiler, 1986; Chone et al., 1991; Eden et al., 1991; Desjardins et al., 1994; Veldkamp, 1994]. In order to understand why some soils increase in carbon storage and others decrease, we require a better understanding of the dynamics of soil carbon storage and turnover in tropical soils.

Sombroek et al. [1993] point out that $\mathrm{C}$ fluxes in soils below 1$m$ depth are generally thought to be insignificant compared to $C$ fluxes in the upper meter. However, a common feature of many soils in terra firme tropical forests is very deep, highly weathered soils which contain significant live-root biomass [Nepstad et al., 1994]. Carbon concentrations below 1-m depth in these soils are usually quite low, for example, $\leq 0.2 \%$ carbon, but even these low concentrations translate into large carbon stocks when tallied over the large volumes of these very deep soils. Furthermore, the presence of living roots at depths greater than $1 \mathrm{~m}$, which may be common for much of Amazonia [Nepstad et al., 1994], suggests active carbon cycling is important at depth in tropical soils. If so, 
changes accompanying deforestation and conversion of large areas of deep-rooting tropical forest to pasture with shallowrooting grasses may cause significant changes in carbon inventory in the soil below $1 \mathrm{~m}$.

Measuring changes in soil $\mathrm{C}$ stocks in pastures at different time intervals following forest conversion is often of limited value because the dynamics of $\mathrm{C}$ cycling are not revealed, and changes in $\mathrm{C}$ stocks that are important over decadal timescales are difficult to detect. We used a combination of isotopic measurements of soil organic matter and soil $\mathrm{CO}_{2}$, measurements of aboveground and belowground $\mathrm{C}$ inputs, and estimates of $\mathrm{CO}_{2}$ production as a function of soil depth to constrain the partitioning of SOM pools with turnover times of years (active $\mathrm{C}$ ), decades (slow C), and more than centuries (passive C). Changes in carbon stocks and isotopic composition accompanying conversion of forest to pastures of different management were predicted by incorporating these three SOM components into a timedependent model.

\section{Site Description}

Figure 1 shows the location of our study, the Fazenda Victoria (Victory Ranch) site, near Paragominas ( $\left.2^{\circ} 59^{\prime} \mathrm{S}, 47^{\circ} 31^{\prime} \mathrm{W}\right)$ in the Brazilian state of Pará. This area was settled in the mid-1960s, coincident with the construction of the Belém-Brasilia highway, and has become a center for logging and ranching. The region of eastern Amazonia surrounding Paragominas experiences seasonal drought, with less than $250 \mathrm{~mm}$ of the total annual precipitation of $1750 \mathrm{~mm}$ falling between June and November. Despite the seasonal water stress, forests in this region retain their leaf canopy year-round. Deep-penetrating (up to $18 \mathrm{~m}$ ) roots of the forest vegetation make this possible by extracting water stored in the soil [Nepstad et al., 1994]. Roughly half of Amazonia experiences a similarly severe seasonal drought yet has

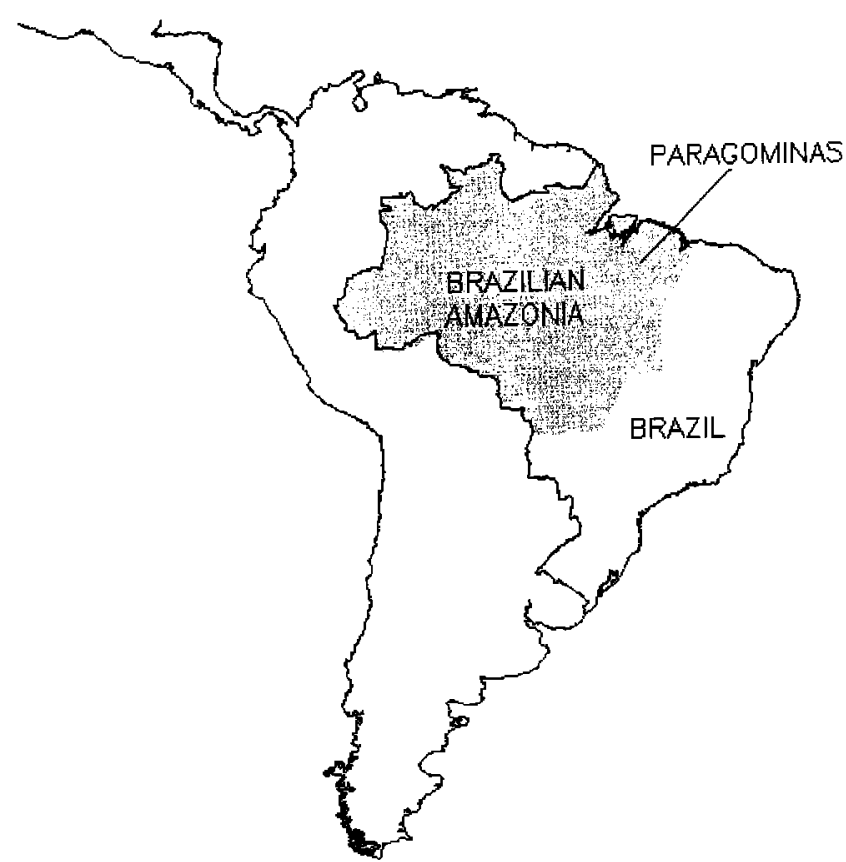

Figure 1. Location of the Fazenda Victoria study area in Paragominas, Pará, Brazil. vegetation which maintains greenness over this period [Nepstad et al., 1994] and thus also probably depends on deep roots to maintain water uptake.

Soils in this region are developed on Pleistocene terraces cut into the Belterra clay and Tertiary Barreiras formations [Sombroek, 1966; Clapperton, 1993]. These sediments consist primarily of kaolinite, quartz, and hematite and are widespread at elevations below $200 \mathrm{~m}$ in Amazonia [Clapperton, 1993]. The soils were classified by Sombroek [1966] as Kaolinitic Yellow Latosols (Haplustox, according to the USDA Soil Taxonomy). Oxisols cover about $40 \%$ of Amazonia [Richter and Babbar, 1991], and are most common in eastern and southern Amazonia where deforestation is concentrated and rainfall is highly seasonal. Soil pits ( $2 \mathrm{~m} \times 1 \mathrm{~m} \times 9 \mathrm{~m}$ deep) were dug at each site to study deep rooting and to monitor the seasonal changes in soil water content; these pits were also used for our soil and trace gas sampling. The water table is below $45 \mathrm{~m}$ at Fazenda Victoria.

To compare soil carbon cycling in pastures and forests, we collected data from soil pits at three mature forest sites, two degraded pasture sites and two managed pasture sites. Pits within each land use type were used as replicates and were located within $0.5 \mathrm{~km}$ of each other. Samples were collected and fluxes measured over the period February 1992 to August 1993 (an unusually dry year locally). The degraded pasture site was originally cleared in 1969, planted with Panicum maximum and later Brachiaria humidicola (both $\mathrm{C} 4$ grasses), and has been heavily grazed intermittently to the present. During clearing, surface slash was bulldozed into windrows; our sites are in the cleared areas. As is common for old pastures in eastern Amazonia, woody shrubs and treelets (C3 plants) now dominate the site, and it supports little grazing [Mattos and Uhl, 1994]. The managed pasture site has a land use history similar to that of the degraded pasture until 1987, when it was disk-harrowed, fertilized with phosphorous, and reseeded with a more productive C4 grass (Brachiaria brizantha). The managed pasture presently has no woody shrubs.

\section{Methods \\ Soll Organic Matter, ${ }^{14} \mathrm{C}$ and ${ }^{13} \mathrm{C}$}

We calculated soil carbon inventory from measurements of bulk density and carbon content (determined from $\mathrm{CO}_{2}$ evolution during high-temperature combustion). Soil samples for degraded pasture and all forest sites were collected in 1992; managed pasture sites were collected in 1993 and 1994. Data reported for 0-10 cm depth intervals are based on composites of eight cores for each site, to account for the large spatial heterogeneity in surface samples (P. Camargo et al., manuscript in preparation, 1995). Samples from depths greater than $10 \mathrm{~cm}$ are discrete. To avoid potential problems of contamination associated with pit walls (which remain open), soil samples were taken after augering at least $1 \mathrm{~m}$ into the side of the pit. Additional samples for managed pasture were obtained by coring from the surface.

The $\delta^{13} \mathrm{C}$ analyses reported here were made at the Centro de Energia Nuclear na Agricultura in Piracicaba, São Paulo, Brazil, and are reported in standard delta notation (Pee Dee Belemnite). Soil organic matter ${ }^{13} \mathrm{C}$ analyses were performed on samples collected separately from those analyzed for $\% \mathrm{C}$ and ${ }^{14} \mathrm{C}$. The precision for ${ }^{13} \mathrm{C}$ analyses is $\pm 0.1 \%$.

The ${ }^{14} \mathrm{C}$ analyses were made by accelerator mass spectrometry (AMS) at the Center for AMS, Lawrence Livermore Laboratory, 
Livermore, California [Southon et al., 1992]. Graphite targets for AMS measurement were prepared using both hydrogen reduction [Vogel et al., 1984] and sealed-tube zinc reduction methods [Vogel, 1992]. Radiocarbon data are expressed in $\Delta^{14} \mathrm{C}$, the per mil deviation from the ${ }^{14} \mathrm{C} /{ }^{12} \mathrm{C}$ ratio of oxalic acid standard in 1950 , with sample ${ }^{14} \mathrm{C} /{ }^{12} \mathrm{C}$ ratio corrected to $-25 \% \delta^{13} \mathrm{C}$ to account for isotopic fractionation effects [Stuiver and Polach, 1977]. Using these units, positive values of $\Delta^{14} \mathrm{C}$ indicate the presence of ${ }^{14} \mathrm{C}$ produced by weapons testing, while negative values indicate that ${ }^{14} \mathrm{C}$ has had time to undergo significant radioactive decay. The precision for radiocarbon analysis is $\pm \mathbf{8}$ $\%$ for values close to Modern ( $0 \%$ ).

All reported $\Delta^{14} \mathrm{C}$ values have been corrected for a sizedependent processing blank determined by combustion of ${ }^{14} \mathrm{C}$ free wood. As several samples from deep in the soil had $\Delta^{14} \mathrm{C}$ values close to this blank value, we attempted to determine whether additional ${ }^{14} \mathrm{C}$ may have been added during treatment of the several hundred grams of soil needed for the ${ }^{14} \mathrm{C}$ measurement. Precombusted soil was mixed with ${ }^{14} \mathrm{C}$-free wood and recombusted. The resulting $\Delta^{14} \mathrm{C}$ value of $-980 \%$ was somewhat bigher than the lowest measured values for deep soil and fractionated organic matter. We assume that any reported ${ }^{14} \mathrm{C}$ value less than $-980 \%$ (equivalent to $2 \%$ Modern carbon) indicates a radiocarbon-free sample.

\section{Fractionation of Soil Organic Matter}

A standard fractionation procedure [Trumbore, 1993; S. E. 'Trumbore and $\mathbf{S}$. Zheng, Comparison of fractionation methods, submitted to Radiocarbon, 1995, hereinafter referred to as Trumbore and Zheng, submitted manuscript, 1995] was used to separate soil organic matter into labile and refractory components. The bulk, $<2 \mathrm{~mm}$ soil was separated by density into greater than and less than $2 \mathrm{~g} \mathrm{~cm}^{-3}$ fractions. Low-density material is primarily undecomposed vascular plant material and charcoal, while high-density material is primarily mineralassociated organic matter. Hydrolysis of the dense fractions $(>\mathbf{g}$ $\mathrm{cm}^{-3}$ ) with a sequence of acids and bases of increasing strength $(0.5 \mathrm{~N} \mathrm{HCl} ; 0.1 \mathrm{~N} \mathrm{NaOH}-\mathrm{Na}$-pyrophosphate; $6 \mathrm{~N} \mathrm{HCl})$ was followed by measurement of $\% \mathrm{C}$ and $\Delta^{14} \mathrm{C}$ of the residue. Combustion, $\mathrm{CO}_{2}$ purification, and graphite target preparation for AMS were the same as for bulk soil samples.

\section{Detrital Carbon Inputs}

Carbon inputs to the soil through fine-root production were estimated from fine-root biomass with the assumption that the average standing stock of fine-root biomass (0-1 $\mathrm{mm}$ diameter) equals the amount of $\mathrm{C}$ added annually to soil for a given depth interval. Fine root ( $0-1 \mathrm{~mm}$ ) biomass was determined by coring to 6-m depth in each ecosystem in July and January of 1992, and July of 1993. Soil samples were taken with augers along transects between pits used for gas and organic matter sampling in the forest (number of cores averaged for each sampling time $=34$ ) and degraded (10 to 16 cores) and managed pastures ( 7 to 20 cores). Auger holes were lined with plastic tubing when each sampling depth was reached to prevent shallower roots from contaminating deeper samples. Fine roots (0-1 mm diameter) were sorted from each $2-\mathrm{kg}$ sample using flotation sieving [Böhm, 1979] and sorted as live or dead under 10x magnification.

Litterfall was measured in the forest as the amount of dry mass falling into thirty $0.25 \mathrm{~m}^{2}$ screen traps and in the pasture as the amount of dead biomass collected from $0.25 \mathrm{~m}^{2}$ plots $(\mathrm{n}=30)$. Litter from both traps and plots was collected at 14-day intervals. Detrital layer dry mass was measured monthly in each ecosystem by harvesting all dead plant material from twenty $0.5 \mathrm{~m}^{2}$ plots. Pasture plots were moved to new locations at 6 month intervals to avoid the effect of biomass harvest on plant production. We assumed litter was $50 \% \mathrm{C}$.

\section{Surface $\mathrm{CO}_{2}$ Fluxes}

Surface fluxes and soil atmosphere $\mathrm{CO}_{2}$ concentrations were measured in forest and degraded pasture in February and May (wet season conditions) 1992 and in November 1992 and August 1993 (dry season conditions). $\mathrm{CO}_{2}$ fluxes were measured by circulating air between the headspace of a flux chamber and the sample cell of a LiCor infrared gas analyzer. Chambers consisted of a polyvinyl chloride (PVC) ring $(20-\mathrm{cm}$ diameter $\times 10-\mathrm{cm}$ height) and a vented PVC cover (10-cm height). PVC bases were either sealed to the litter layer surface using low $C$ content clay from deep soil layers (forest) or inserted $1-2 \mathrm{~cm}$ into mineral soil (pastures). Living vegetation inside the collars was clipped. $\mathrm{CO}_{2}$ flux was determined as the slope of a best fit line to the concentration increase in the chamber headspace after the cover was placed on the base $(5 \mathrm{~min}$.). The rate of flow between the chamber and the $\mathrm{LiCor}$ instrument was $0.7 \mathrm{~L} \mathrm{~min} \mathrm{~m}^{-1}$. Other details are given in Davidson and Trumbore [1995].

\section{Concentration Gradient in Soil Atmosphere}

Samples of soil atmosphere at various depths were obtained by syringe from gas-sampling tubes installed 1-2 $\mathrm{m}$ into the pit walls. Measurements of the $\mathrm{CO}_{2}$ concentration in soil air space used a different LiCor configuration [Davidson and Trumbore, 1995]. A known volume sample (usually $0.5-2 \mathrm{~cm}^{3}$ ) was injected into an air stream from which $\mathrm{CO}_{2}$ had been scrubbed, then passed through the LiCor sample cell. The LiCor response with time was again recorded by a data logger at $1 \mathrm{~Hz}$. The integrated area under the response versus time curve was converted to a $\mathrm{CO}_{2}$ concentration using a calibration curve derived from injections of different volumes of a standard gas.

Soil moisture was monitored weekly by time-domain reflectometry (TDR) [Topp and Davis, 1985; Nepstad et al., 1994]. An exponential curve fit to the $\mathrm{CO}_{2}$ gradient in soil atmosphere, combined with effective diffusivity estimated from TDR and soil structural data [Millington and Shearer, 1971] was used to calculate $\mathrm{CO}_{2}$ production required to maintain observed steady state $\mathrm{CO}_{2}$ profiles. Details are given by Davidson and Trumbore [1995].

\section{Isotopic measurements of ${ }^{14} \mathrm{C}$ and ${ }^{13} \mathrm{C}$ in Soil Atmosphere $\mathrm{CO}_{2}$}

Samples of soil gas for isotopic analysis were obtained by filling preevacuated electropolished aluminum cans $\left(500 \mathrm{~cm}^{3}\right.$ volume) from sampling tubes installed in the soil pit walls. $\mathrm{CO}_{2}$ was purified from the air either cryogenically (May 1992 data) or using a molecular sieve (13X) trap (November 1992 and later data [Bauer et al., 1992]). The ${ }^{13} \mathrm{C}$ measurements were made primarily to correct ${ }^{14} \mathrm{C}$ data for fractionation effects during sampling or purification; however, data are presented for interpretation as well. $\mathrm{N}_{2} \mathrm{O}$ was not separated from $\mathrm{CO}_{2}$ prior to 

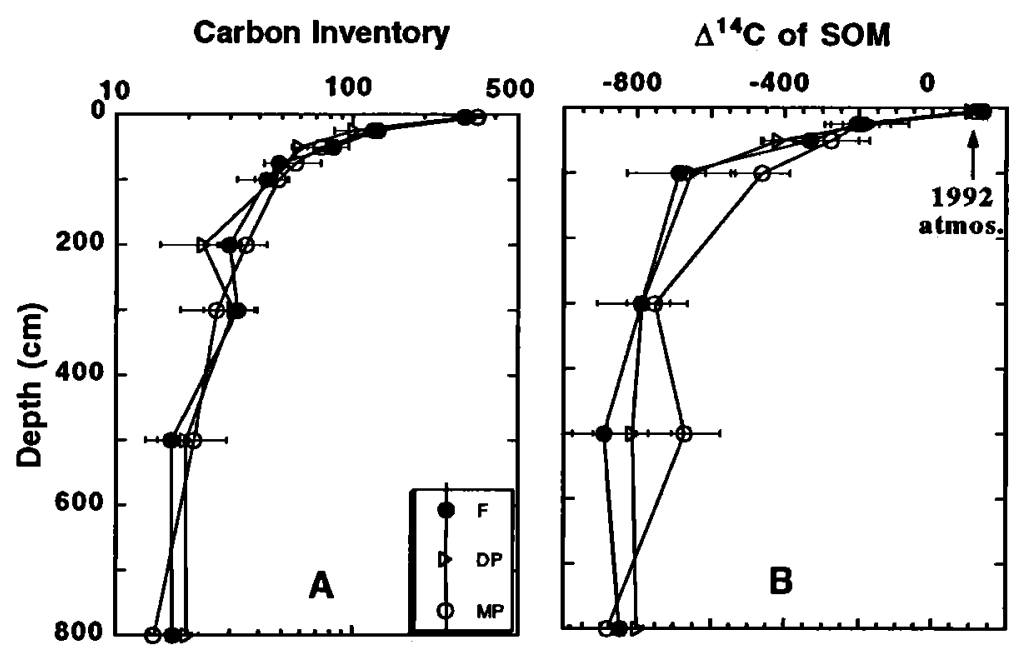

Figure 2. (a) Carbon inventory and (b) $\Delta^{14} \mathrm{C}$ contents of soil organic matter in mature forest (average of three pits), degraded pasture (average of two pits) and managed pasture (average of one core plus one pit) sites. Carbon inventory is for bulk soil and is calculated from bulk density and gravimetric \% C data. It is plotted on a log scale (Figure 2a) to emphasize differences between forest and pasture sites (significant only in the upper $1 \mathrm{~m}$ for both inventories and isotopes). Error bars represent standard deviations of the means. Integrated values for depth intervals given in Table 1 are based on linear interpolations between depth intervals, as plotted on the graphs. F, forest; DP, degraded pasture; MP, managed pasture.

mass spectrometry measurement; soil $\mathrm{N}_{2} \mathrm{O}$ concentrations between 0.5 and $1.8 \mathrm{ppm}$, which we have measured in soil atmospheres (E. A. Davidson, unpublished data, 1993). will result in error in ${ }^{13} \mathrm{C}$ measurement of up to $1 \%$ [Mook and Jonsma, 1987].

\section{RESULTS}

\section{Distribution of Carbon and Radiocarbon in Soll Organic Matter}

Figure 2 summarizes the carbon density (Figure 2a) and radiocarbon (Figure $2 \mathrm{~b}$ ) contents of bulk organic matter $(<2 \mathrm{~mm}$ ) in the mature forest (average of three pits), degraded pasture (two pits), and managed pasture (one core plus one pit). Carbon content drops off steeply in the upper meter of forest and pasture soils, leveling off at values corresponding to $0.10-0.20 \mathrm{wt} \% \mathrm{C}$ (air-dry basis) below $300 \mathrm{~cm}$. Nonetheless, the large volume of deep soil (1-8 m) contains roughly $60 \%\left(17-18 \mathrm{kgC} \mathrm{m}^{-2}\right)$ of the total carbon inventory of all soils to $8 \mathrm{~m}\left(28 \pm 5 \mathrm{kgC} \mathrm{m}^{-2}\right.$; Table 1). The total $\mathrm{C}$ stored in soils to $8 \mathrm{~m}$ is approximately 1.5 times the amount of carbon stored in aboveground forest biomass [Nepstad et al., 1995].

Attempts to measure differences in soil carbon inventory between forests and the pastures that replace them are confounded by concurrent changes in soil physical properties [Davidson and Ackerman, 1993; Veldkamp, 1993; Veldkamp, 1994]. Although the $\% \mathrm{C}$ measured in the upper $10 \mathrm{~cm}$ of degraded pasture soils (ranging between 2.52 and $2.68 \% \mathrm{C}$; Table 2) is significantly lower than that of the mature forest (2.74-3.18 $\% \mathrm{C}$ ), the bulk density is higher by about $20 \%$ in both pasture types $\left(1.20-1.22 \mathrm{~g} \mathrm{~cm}^{-3}\right)$ compared to the forest $\left(0.96-1.02 \mathrm{~g} \mathrm{~cm}^{-}\right.$ ${ }^{3}$ ). If we compare soil on a common-depth basis, the carbon inventory (in $\mathrm{g} \mathrm{C} \mathrm{m}^{-2}$ ) calculated for the $0-10 \mathrm{~cm}$ layer of degraded pasture is greater than that of the forest. Instead, we compare the soils on a common mass basis to avoid artifacts resulting from soil compaction [Davidson and Ackerman, 1993; Veldkamp, 1993; Veldkamp, 1994]. The C inventory in the 0-10 $\mathrm{cm}$ layer of the forest is thus compared to the $0.8 \mathrm{~cm}$ layer in the pastures (Table 1). This comparison shows a loss of $15 \%(0.4 \mathrm{~kg}$ $\mathrm{C} \mathrm{m}^{-2}$ ) of soil carbon when forest is converted to degraded pasture. While this loss is significant relative to errors in bulk density and $\mathrm{C}$ concentration determinations (see below), the fact that bulldozing of pastures during clearing may have scraped up to $5 \mathrm{~cm}$ of soil from some areas gives us little confidence in interpreting differences in $\mathrm{C}$ stocks in this soil layer.

Differences in $\mathrm{C}$ inventory between forest and pasture soils are small relative to our measurement errors. The combined errors in replicate samples collected for bulk density $( \pm 10 \%)$ and multiple determination of $\% \mathrm{C}$ from one sample $( \pm 2-5 \%$ for values above $0.5 \% \mathrm{C}$ ) indicate that differences in surface soil carbon inventory of less than $11 \%$ are not significant for the surface meter of soil. Thus differences between forest and degraded and managed pastures at $10-100 \mathrm{~cm}$ depth $(8-100 \mathrm{~cm}$ in the pasture) are not significant (Table 1). Seemingly large differences in $\mathrm{C}$ inventory between forest and pastures in the deep soil are also not significant (Table 1). Error in our analytical determination of $\% \mathrm{C}$ increases to nearly $20 \%$ of the measured value at low $(<0.2 \% \mathrm{C})$ concentrations. Combined with errors in bulk density (again $\pm 10 \%$ ), the overall error in the estimate of carbon inventory in the deep soil is $\pm 22 \%$. Thus even potentially large (1-5 $\mathrm{kg} \mathrm{C} \mathrm{m}^{-2}$ ) changes in carbon inventory accompanying land use change are nearly impossible to detect from concentration measurements alone in these soils.

The degree to which ${ }^{14} \mathrm{C}$ produced by atmospheric thermonuclear weapons testing in the early 1960s has infiltrated soil organic matter may be used to assess the amount of organic matter turning over on decadal and shorter timescales (slow plus 
Table 1. Average C Inventory and Isotopic Character of SOM for Forest, Degraded, and Managed Pastures

\begin{tabular}{|c|c|c|c|c|c|c|c|c|c|c|}
\hline \multirow[b]{2}{*}{ Depth } & \multicolumn{4}{|c|}{ Carbon Inventory $\left(\mathrm{kg} \mathrm{C} \mathrm{m}^{-2}\right)$} & \multicolumn{3}{|c|}{ Carbon $14(\Delta \% 0)$} & \multicolumn{3}{|c|}{ Carbon $13(\delta . \% 0)$} \\
\hline & $\mathrm{F}$ & DP & MP & $\mathrm{MDD}^{\mathrm{a}}$ & F & DP & MP & $\mathbf{F}$ & DP & MP \\
\hline $\begin{array}{l}0-10 \mathrm{~cm}^{\mathrm{b}} \\
10-100 \mathrm{~cm} \\
100-300 \mathrm{~cm} \\
300-500 \mathrm{~cm} \\
500-800 \mathrm{~cm}\end{array}$ & $\begin{array}{l}2.6 \\
7.6 \\
6.6 \\
3.8 \\
5.1\end{array}$ & $\begin{array}{l}2.2 \\
7.8 \\
7.3 \\
5.1 \\
7.6\end{array}$ & $\begin{array}{l}2.3 \\
8.5 \\
7.0 \\
4.5 \\
6.1\end{array}$ & $\begin{array}{l}0.3 \\
0.8 \\
1.6 \\
1.1 \\
1.7\end{array}$ & $\begin{array}{l}+137 \\
-321 \\
-727 \\
-806 \\
-834\end{array}$ & $\begin{array}{l}+107 \\
-346 \\
-705 \\
-794 \\
-757\end{array}$ & $\begin{array}{l}+117 \\
-210 \\
-600 \\
-740 \\
\text { ND }\end{array}$ & $\begin{array}{l}-27.3 \\
-26.6 \\
-24.8 \\
-24.3 \\
-23.6\end{array}$ & $\begin{array}{l}-24.8 \\
-25.7 \\
-24.8 \\
-23.7 \\
-23.3\end{array}$ & $\begin{array}{l}-24.0 \\
-25.1 \\
-24.4 \\
-24.2 \\
\text { ND }\end{array}$ \\
\hline Total & 25.7 & 30.0 & 28.4 & 5.5 & & & & & & \\
\hline
\end{tabular}

\begin{abstract}
F, forest; DP, degraded pasture; MP, managed pasture; ND, not determined. Values in this table were calculated using linear interpolation between discrete depths for which $\% C$ and carbon isotopes were measured: $25,50,75,100$, $300,500,800 \mathrm{~cm}$ (see Figure 2).

a Minimum detectible difference (MDD) is calculated by combining uncertainties in bulk density and C concentration analyses (see text). Differences between forest and pasture soils less than these values may not be significant. Minimum detectible differences for isotopic analyses, estimated from the standard deviation from the mean of the 3 forest and 2 pasture sites averaged here, are $\pm 25 \%$ for the upper meter $( \pm 100 \%$ deeper than $1 \mathrm{~m})$ and $0.25 \% \circ(0-1 \mathrm{~m})$ to $0.5 \%(1-8$ m) for $\mathrm{d}^{13} \mathrm{C}$.

b $0-10 \mathrm{~cm}$ values are averages of 8 composited cores taken at each site ( $\mathrm{n}=3$ for forest sites, 2 for degraded pasture and 2 for managed pasture). Pastures were sampled as $0-10 \mathrm{~cm}$, but the $\% \mathrm{C}, \Delta^{14} \mathrm{C}$ and $\delta^{13} \mathrm{C}$ values obtained were applied to only the upper $8 \mathrm{~cm}$ when calculating $\mathrm{C}$ inventory (see text).
\end{abstract}

active pools), as opposed to millennial and longer (passive pool) timescales. Figure $2 \mathrm{~b}$ shows a rapid decrease in the $\Delta^{14} \mathrm{C}$ of SOM from the surface of the soil, leveling off at very low values $(-700$ to $-800 \%$ ) below $3-\mathrm{m}$ depth. The high positive values of $\Delta^{14} \mathrm{C}$ at the soil surface suggest rapid ( $<30$ years) turnover times for most of the organic matter in the $0-10 \mathrm{~cm}$ layer. Error bars in Figure $2 \mathrm{~b}$ are the standard deviation from the mean of individual pit values and are larger than analytical error $\left( \pm 8 \%\right.$ in $\left.\Delta^{14} \mathrm{C}\right)$.

The ${ }^{14} \mathrm{C}$ content of soil organic matter is a more sensitive indicator of carbon accumulation or loss over the past several decades than carbon inventory measurements. Degraded pasture ${ }^{14} \mathrm{C}$ values in the $0-8 \mathrm{~cm}$ layer are less than those of the $0-10 \mathrm{~cm}$ forest soil layer (Table 1). The low $\left(+107 \%\right.$ ) bulk ${ }^{14} \mathrm{C}$ content of the $0-8 \mathrm{~cm}$ degraded pasture organic matter suggests most of the carbon fixed by the forest between 1963 and the time of clearing in 1969 has been lost (these dates bracket times of highest atmospheric $\Delta^{14} \mathrm{C}$ values), and the amount of new carbon derived from pasture vegetation sources is small relative to post-1969 forest $\mathrm{C}$ inputs. Managed pasture $\Delta^{14} \mathrm{C}$ values are intermediate between degraded pasture and forest values in the $0-8 \mathrm{~cm}$ layer but are significantly greater than those of the forest or degraded pasture in the $8-100 \mathrm{~cm}$ depth range (Table 1).

Deep-soil radiocarbon values may be interpreted in two ways. First, they could represent the average residence time of carbon in the deep soil (in this case, a $\Delta^{14} \mathrm{C}$ value of $-800 \%$ would be equivalent to a turnover time of 40,000 years). Inherent in this calculation is the assumption that this is a homogeneous reservoir in which all carbon is turning over at the same rate. In the other extreme, the soil organic matter could be a two-component mixture of $10 \%$ contemporary (1992 atmosphere) carbon $\left(\Delta^{14} \mathrm{C}\right.$ of $+143 \%$ ) mixed with radiocarbon-free material. As will be shown below, evidence from chemical fractionation of the SOM, and the ${ }^{14} \mathrm{C}$ content of $\mathrm{CO}_{2}$ produced below $3 \mathrm{~m}$ depth, supports a mixture of fast-cycling and inert $\mathrm{C}$ as the most logical interpretation of the radiocarbon data.

The change in ${ }^{13} \mathrm{C}$ content of soil organic matter following conversion of forest to pasture may be used to follow the loss of original forest-derived (C3) carbon and accumulation of new pasture-derived (C4) carbon [Balesdent et al., 1987; Vitorello et al., 1989; Cerri et al., 1991; Hseih, 1992; Desjardins et al., 1994; Veldkamp, 1994; Townsend et al., 1995]. This approach is based on the large difference between the $\delta^{13} \mathrm{C}$ of plants with C3 $(-25$ to $-32 \%$ ) and $C 4(-12$ to $-15 \%$ ) photosynthetic pathways. The $\delta^{13} \mathrm{C}$ of SOM near the surface in both degraded and managed pasture soils has increased only slightly since 1969 from values typical of forest-derived soil organic matter of $-27 \%$ to -24 or $-25 \%$ (Table 1). Assuming that pastures with $100 \% \mathrm{C} 4$ carbon inputs will have SOM $\delta^{13} \mathrm{C}$ values of $-14 \%$ to $-12 \%$, we calculate that only about $16-21 \%$ of the SOM in 1992 pastures in this depth interval is derived from $\mathrm{C} 4$ plants [P. Camargo, manuscript in preparation, 1995]. This calculation could underestimate the amount of recently added $C$, however, as degraded pastures have significant (but as yet unquantified) $\mathrm{C}$ inputs from $\mathrm{C} 3$ woody plants. Values for ${ }^{13} \mathrm{C}$ in the upper meter of the managed pasture are slightly more enriched in ${ }^{13} \mathrm{C}$ than degraded pastures. Differences in ${ }^{13} \mathrm{C}$ between the soils at $>1-\mathrm{m}$ depth are not significant.

\section{Distribution of $\mathrm{C}$ and ${ }^{14} \mathrm{C}$ in fractions}

Results of $\mathrm{C}$ and ${ }^{14} \mathrm{C}$ measurements of physically and chemically fractionated organic matter (Table 2) may be used to break soil organic matter down into constituent fast-cycling (active plus slow pools) and passive pools. The majority of the carbon in tropical forest and pasture soils is present in association with mineral surfaces (the dense fraction, $>2 \mathrm{~g} \mathrm{~cm}^{-3}$ ) [Jenny et al., 1949; Trumbore, 1993; Trumbore and Zheng, submitted manuscript, 1995]. Roughly $30 \%$ of the total carbon in the upper $10 \mathrm{~cm}$ of the forest soil is present as low density material, mostly $<2 \mathrm{~mm}$ roots and vascular plant detrital material. Low-density $\Delta^{14} \mathrm{C}$ values in this layer average $+162 \%$ in the forest, higher than those of 1992 forest leaves $(+143 \%$ ), indicating that this fraction is dominated by $\mathrm{C}$ fixed more than 2 but less than 10 years ago. The average $\Delta^{14} \mathrm{C}$ value for the dense fraction of 
Table 2. Results of Chemical Fractionation Procedures for Soil Organic Matter ${ }^{14} \mathrm{C}$

\begin{tabular}{|c|c|c|c|c|c|c|c|c|c|}
\hline \multirow[b]{2}{*}{ Depth } & \multirow[b]{2}{*}{$\% \mathrm{C}$} & \multirow{2}{*}{$\begin{array}{l}\text { Bulk Soil } \\
\text { Inventory }\end{array}$} & \multirow[b]{2}{*}{$\Delta^{14} C$} & \multicolumn{2}{|c|}{ Low Density } & \multicolumn{2}{|c|}{ Density $>2.0$} & \multicolumn{2}{|c|}{ Hydrolysis Residue } \\
\hline & & & & $\% \mathrm{C}_{\mathrm{t}}$ & $\Delta^{14} \mathrm{C}$ & $\% \mathrm{C}_{\mathrm{t}}$ & $\Delta^{14} \mathrm{C}$ & $\% \mathrm{C}_{\mathrm{t}}$ & $\Delta^{14} \mathrm{C}$ \\
\hline $\begin{array}{l}\text { Forest C } \\
0-10 \mathrm{~cm}\end{array}$ & 2.7 & 260 & +130 & 24 & +174 & 76 & +116 & ND & ND \\
\hline $\begin{array}{l}0-2.5 \mathrm{~cm} \\
10-15 \mathrm{~cm}\end{array}$ & $\begin{array}{l}4.5 \\
1.5\end{array}$ & $\begin{array}{l}430 \\
170\end{array}$ & ${ }_{\mathrm{ND}}^{+163^{\mathrm{a}}}$ & $\begin{array}{l}25 \\
<5\end{array}$ & $\begin{array}{r}+170 \\
\text { ND }\end{array}$ & $\begin{array}{r}75 \\
>95\end{array}$ & $\begin{array}{l}+160 \\
-207\end{array}$ & $\begin{array}{l}21 \\
15\end{array}$ & $\begin{array}{r}+114 \\
-280\end{array}$ \\
\hline $\begin{array}{l}25 \mathrm{~cm} \\
100 \mathrm{~cm}\end{array}$ & $\begin{array}{l}1.0 \\
0.4\end{array}$ & $\begin{array}{r}130 \\
50\end{array}$ & $\begin{array}{r}-89 \\
-470\end{array}$ & $<5$ & ${ }_{\text {ND }}^{+177^{a}}$ & $\begin{array}{l}>95 \\
>95\end{array}$ & $\begin{array}{l}-103 \\
-552\end{array}$ & $\begin{array}{l}14 \\
15\end{array}$ & $\begin{array}{l}-237 \\
-853\end{array}$ \\
\hline $\begin{array}{l}\text { Forest B } \\
0-10 \mathrm{~cm} \\
25 \mathrm{~cm} \\
100 \mathrm{~cm}\end{array}$ & $\begin{array}{l}3.2 \\
0.9 \\
0.2\end{array}$ & $\begin{array}{l}310 \\
\text { ND } \\
\text { ND }\end{array}$ & $\begin{array}{r}+147 \\
\text { ND } \\
\text { ND }\end{array}$ & $\begin{array}{l}34 \\
<5 \\
<5\end{array}$ & $\begin{array}{r}+166 \\
\text { ND } \\
\text { ND }\end{array}$ & $\begin{array}{r}66 \\
>95 \\
>95\end{array}$ & $\begin{array}{r}+138 \\
-258 \\
-829\end{array}$ & $\begin{array}{r}\text { ND } \\
22 \\
13\end{array}$ & $\begin{array}{r}\text { ND } \\
-601 \\
-940\end{array}$ \\
\hline $\begin{array}{l}\text { Forest E } \\
0-10 \mathrm{~cm}\end{array}$ & 3.2 & 320 & +137 & 26 & +147 & 74 & +133 & ND & ND \\
\hline Degraded I & & & & & & & & & \\
\hline $\begin{array}{l}0-10^{b} \mathrm{~cm} \\
0-2.5 \mathrm{~cm} \\
10-15 \mathrm{~cm} \\
100 \mathrm{~cm}\end{array}$ & $\begin{array}{l}2.7 \\
3.7 \\
1.2 \\
0.4\end{array}$ & $\begin{array}{r}220 \\
450 \\
150 \\
50\end{array}$ & $\begin{array}{r}+113 \\
\text { ND } \\
\text { ND } \\
\text { ND }\end{array}$ & $\begin{array}{r}18 \\
58 \\
8 \\
<5\end{array}$ & $\begin{array}{r}+133 \\
+108 \\
\text { ND } \\
\text { ND }\end{array}$ & $\begin{array}{r}82 \\
42 \\
92 \\
>95\end{array}$ & $\begin{array}{l}+96 \\
+30 \\
-141 \\
-627\end{array}$ & $\begin{array}{r}\text { ND } \\
33 \\
13 \\
14\end{array}$ & $\begin{array}{r}\text { ND } \\
-7 \\
-397 \\
-940\end{array}$ \\
\hline Degraded F & & & & & & & & & \\
\hline $0-10^{b} \mathrm{~cm}$ & 2.5 & 250 & +107 & 16 & +97 & 84 & +108 & ND & ND \\
\hline $\begin{array}{l}\text { Managed } P \\
0-10^{b} \mathrm{~cm}\end{array}$ & 2.7 & 280 & +122 & $<5$ & +160 & $>95$ & +113 & ND & ND \\
\hline
\end{tabular}

ND, not determined. The $0-10 \mathrm{~cm}$ intervals are based on composites of eight separate cores. \%C, gravimetric $\mathrm{C}$ content of bulk organic matter; Inventory, $\mathrm{g} \mathrm{C} \mathrm{m}^{-2}$ per $\mathrm{cm}$ obtained by multiplying the $\% \mathrm{C}$ by the measured bulk density for that interval; $\% \mathrm{C}_{\mathrm{t}}$, percent of the bulk soil carbon inventory present in a particular organic matter fraction.

${ }^{\mathrm{A}} \mathrm{Calculated}$ from mass balance of $\mathrm{C}$ and ${ }^{14} \mathrm{C}$.

${ }^{B}$ Although analyses were performed on $0-10 \mathrm{~cm}$ cores, pasture $C$ inventories reported in Table 1 are based on the assumption that the upper $8 \mathrm{~cm}$ of pasture soil is comparable on an equal-mass basis with $0-10 \mathrm{~cm}$ of forest soil (see test).

organic matter in the upper $10 \mathrm{~cm}$ of the forest soil $(+129 \%)$ is less than the 1992 value of forest vegetation. Further fractionation shows this average reflects a mixture of components containing both more depleted (hydrolysis residue) and more enriched (bydrolyzable $\mathrm{C}$ ) ${ }^{14} \mathrm{C}$ (Table 2 ). The amount of lowdensity material drops off rapidly with depth in the soil to undetectable ( $<5 \%$ of the total C) levels below about $25 \mathrm{~cm}$. Live- and dead-root biomass (presumably most of the lowdensity carbon at depth) each represent less than $2 \%$ of the total forest soil carbon at depths $>100 \mathrm{~cm}$.

Low-density organic matter accounts for less than $20 \%$ of the total $\mathrm{C}$ in the upper $10 \mathrm{~cm}$ of degraded and managed pasture soils. Degraded pasture $\Delta^{14} \mathrm{C}$ values in this layer are lower than those of the forest for both density fractions. Managed pasture values for low-density material approach forest values in the $\mathbf{0 - 8}$ $\mathrm{cm}$ layer and are intermediate in $\Delta^{14} \mathrm{C}$ between degraded pasture and forest values for the dense fraction.

Further fractionation of the dense $\left(>2 \mathrm{~g} \mathrm{~cm}^{-3}\right)$ organic matter by a sequence of increasingly harsh chemical procedures removes up to $80 \%$ of the dense fraction carbon, leaving a residue depleted in ${ }^{14} \mathrm{C}$ (Table 2). At a depth of $100 \mathrm{~cm}$, the acid-baseacid treatment removes essentially all ${ }^{14} \mathrm{C}\left(\Delta^{14} \mathrm{C}\right.$ values less than $-980 \%$ are considered indistinguishable from blank values; see above). Mass balance calculations to determine the $\Delta^{14} \mathrm{C}$ of carbon removed by hydrolysis show that the hydrolyzed material, although enriched in ${ }^{14} \mathrm{C}$ compared to the unhydrolyzed residue or original untreated material, is still significantly depleted in ${ }^{14} \mathrm{C}$ compared to 1992 vegetation values and therefore probably contains some $\mathrm{C}$ with millennial turnover times. Hence the absolute abundance of ${ }^{14} \mathrm{C}$-depleted nonhydrolyzable organic carbon (15-20\% of the bulk carbon in the unfractionated sample) may be taken as the minimum abundance of a passive (refractory) carbon pool.

Samples taken deeper than $100 \mathrm{~cm}$ were not subjected to acidbase-acid hydrolysis, because of extremely low carbon contents and the problem of determining a "zero radiocarbon" blank value for soil samples. We have assumed that samples deeper than 100 $\mathrm{cm}$ will also leave essentially radiocarbon-free residues after acid-base-acid hydrolysis.

\section{Carbon Inputs From Vascular Plants}

Surface litter inputs (average for 1991-1992 of 9.1 Mg oven dry weight $\mathrm{ha}^{-1} \mathrm{yr}^{-1}$ ) in the forest are approximately triple those observed in degraded pastures (average of $2.8 \mathrm{Mg} \mathrm{ha}^{-1} \mathrm{yr}^{-1}$ ). The litterfall rates in forests at Fazenda Victoria are $10-60 \%$ higher than those reported by Klinge and Rodriguez [1968] (4.8 - 6.4 $\mathrm{Mg} \mathrm{ha}^{-1} \mathrm{yr}^{-1}$ ) or Luizao and Schubart [1987] (8.25 Mg ha-1 $\mathrm{yr}^{-1}$ ) for nutrient poor terra firme forests in the vicinity of Manaus. We assumed dry matter averaged $50 \%$ carbon by weight when calculating annual litter carbon inputs (given in Table 3 ). Comparison of the amount of forest floor detritus (annual average $6.5 \mathrm{Mg} \mathrm{ha}^{-1}$ ) with annual inputs supports the idea of short $(<1$ year) residence times for most forest litter components. Rapid 
Table 3. Balance of Carbon Inputs and Losses for Forest, Degraded, and Managed Pasture Soils

\begin{tabular}{|c|c|c|c|c|c|c|c|}
\hline & \multicolumn{3}{|c|}{ Forest } & \multicolumn{4}{|c|}{ Degraded Pasture Managed Pasture } \\
\hline & Inputs & $\mathrm{CO}_{2}$ & $\mathbf{R R}$ & Inputs & $\mathrm{CO}_{2}$ & Inputs & $\mathrm{CO}_{2}$ \\
\hline $\begin{array}{l}\text { Litter } \\
0-10 \mathrm{~cm} \\
10-100 \mathrm{~cm}\end{array}$ & $\begin{array}{r}450 \\
60 \\
130\end{array}$ & & & $\begin{array}{r}140 \\
30 \\
90\end{array}$ & & $\begin{array}{l}200 \\
110 \\
230\end{array}$ & \\
\hline $\mathrm{L}-100 \mathrm{~cm}$ & 640 & 1960 & $67 \%$ & 260 & 750 & 540 & 1380 \\
\hline $\begin{array}{l}100-300 \mathrm{~cm} \\
300-500 \mathrm{~cm}\end{array}$ & $\begin{array}{l}70 \\
20\end{array}$ & & & $\begin{array}{l}80 \\
50\end{array}$ & & $\begin{array}{c}20 \\
2\end{array}$ & \\
\hline $100-500 \mathrm{~cm}$ & 90 & 190 & $50 \%$ & 120 & 220 & 22 & 250 \\
\hline
\end{tabular}

Inputs, $\mathrm{C}$ flux added to the soil from 0-1 mm roots, assuming annual turnover; $\mathrm{CO}_{2}, \mathrm{C}$ flux from root respiration and decomposition, as determined by Davidson and Trumbore [1995]; RR, root respired $\mathrm{CO}_{2}$, calculated from Inputs minus $\mathrm{CO}_{2}$ produced in a given depth interval. Root input data are averages of samples collected in July 1992, January 1993 , and July $1993.95 \%$ confidence intervals range from $30-80 \%$ of the mean for cores averaged for any given sampling date.

(annual or faster) turnover of surface detritus is also deduced from the studies of Klinge and Rodriguez [1968] and Luizão and Schubart [1987].

Table 3 presents data on carbon inputs estimated from fine root biomass for the three systems considered here [Nepstad et al., 1994] . We estimate the input rate for belowground detrital carbon by assuming annual turnover of fine-root $(<1 \mathrm{~mm}$ ) biomass. Two lines of evidence support this assumption. First, the ${ }^{14} \mathrm{C}$ content of living $<1 \mathrm{~mm}$ roots averages $+137 \%$ o $(n=5)$, close to 1992 atmospheric values. Second, dead-root biomass approximately equals live-root biomass in forests (D.C. Nepstad, unpublished data, 1995); thus the rate of addition of $\mathrm{C}$ to the dead-root pool must roughly equal the rate of $C$ loss by decay. Preliminary results of decomposition experiments suggest turnover times of approximately 1 year for dead roots (D. C. Nepstad, unpublished data, 1995). Expanding the root input estimate to include 1-2 mm diameter roots would increase values in the upper meter of forest soils by roughly $10 \%$ and in degraded and managed pastures by $20 \%$ and $30 \%$, respectively (again assuming annual turnover). As is common in studies of fine-root biomass [Nadelhoffer and Raich, 1992], variation was high in our measurements of fine-root biomass, with $95 \%$ confidence

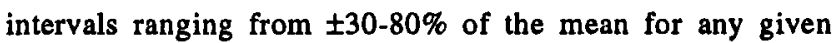
sampling date. The standard deviation of the mean for the three dates averaged less than $50 \%$ of the values in Table 3 .

Most (65-70\%) of the fine-root ( $<1 \mathrm{~mm}$ ) biomass to 8-m depth is present in the upper meter of the forest soil. In the degraded pasture, deep root inventories are similar to those of the forest, but those in the surface meter are reduced to about $65 \%$ of forest values. Presumably, the presence of regrowing trees in this pasture is responsible for the presence of deep roots. Managed pastures provide the strongest contrast with forest-root distributions. Live roots are nearly twice as abundant in the upper meter as in forest soils (adding 0-1 mm dead-root biomass to both increases this to 4-5 times more abundant), while depths greater than $3 \mathrm{~m}$ have almost no fine roots. Elevated root abundance in the $\mathbf{0 - 3} \mathrm{m}$ depth interval is attributed to the high belowground productivity of some Brachyaria grasses
[Veldkamp, 1993; Fisher et al., 1994]. The lack of deep roots in the managed pasture is due to the absence of trees and decomposition of any residual fine roots from forest vegetation.

\section{$\mathrm{CO}_{2}$ Production in Soil}

The $\mathrm{CO}_{2}$ flux measured at the soil surface is produced by root respiration and decomposition of soil organic matter. Average $1992 \mathrm{CO}_{2}$ fluxes in forests $\left(\mathrm{n}=3\right.$ ) ranged from $240 \mathrm{mg} \mathrm{C} \mathrm{m}^{-2} \mathrm{~h}^{-1}$ in the dry season to $290 \mathrm{mg} \mathrm{C} \mathrm{m} \mathrm{m}^{-2} \mathrm{~h}^{-1}$ in the wet season. Degraded pasture fluxes were consistently smaller, ranging from $110 \mathrm{mg} \mathrm{C} \mathrm{m}^{-2} \mathrm{~h}^{-1}$ in the dry season to $140 \mathrm{mg} \mathrm{C} \mathrm{m}^{-2} \mathrm{~h}^{-1} \mathrm{n}$ the wet season. Managed pasture fluxes were intermediate, with fluxes averaging $140 \mathrm{mg} \mathrm{C} \mathrm{m} \mathrm{h} \mathrm{h}^{-1}$ (dry season) to $230 \mathrm{mg} \mathrm{C} \mathrm{m}^{-2} \mathrm{~h}^{-1}$ (wet season). We observed no detectable day-night fluctuations in $\mathrm{CO}_{2}$ flux in either forest or degraded pasture sites. The primary forest soil $\mathrm{CO}_{2}$ fluxes at Fazenda Victoria are roughly $20 \%$ larger than values measured in terra firme forest in the Reserva Ducke near Manaus [Fan et al., 1990], which also showed little seasonality.

Surface $\mathrm{CO}_{2}$ fluxes are supported in part by the large concentration gradient of $\mathrm{CO}_{2}$ in the soil, shown in Figure 3a. $\mathrm{CO}_{2}$ concentrations increase with depth throughout the 8-m depth interval (Figure $3 \mathrm{a}$ ), indicating $\mathrm{CO}_{2}$ production deeper than $8 \mathrm{~m}$ in the soil. The degraded pasture has lower $\mathrm{CO}_{2}$ concentration below $300 \mathrm{~cm}$ than the forest. High $\mathrm{CO}_{2}$ concentrations at depth result from modest $\mathrm{CO}_{2}$ production rates (compared to surface values) coupled with slow diffusion [Davidson and Trumbore, 1995] We estimated $\mathrm{CO}_{2}$ production as a function of soil depth from Fick's law, assuming a steady state diffusive profile for $\mathrm{CO}_{2}$ and estimating effective diffusivity in the soil using published models relating diffusivity to soil moisture and structure [Millington and Shearer, 1971]. The resulting $\mathrm{CO}_{2}$ production rates are summarized in Table 3 (details given by Davidson and Trumbore [1995]). Overall, $\mathrm{CO}_{2}$ production deeper than $1 \mathrm{~m}$ in the soil accounts for $20-30 \%$ of the measured surface flux [Davidson and Trumbore, 1995].

$\mathrm{CO}_{2}$ production may be from root respiration or decomposition of soil organic matter (including dead roots). Comparison of estimated annual inputs of carbon (from aboveground and belowground detrital turnover) with $\mathrm{CO}_{2}$ production rates (Table 3 ) suggests that root respiration contributes $50-65 \%$ of the $\mathrm{CO}_{2}$ flux in the forest soil (assumed to be at steady state). Autotrophic and heterotrophic respiration in soils are difficult to distinguish by any method, but most estimates have indicated roughly equal contributions to total soil respiration [Bowden et al., 1993]. Given the uncertainties in our estimates, our results agree with this $50-50$ characterization. The more important conclusion is that our assumption of annual turnover of fine-root biomass yields reasonable estimates of heterotrophic and autotrophic respiration. Production of $\mathrm{CO}_{2}$ by depth is also calculated for degraded and managed pastures in Table 3, but it should be remembered that these are nonsteady state soils, and $\mathrm{C}$ inputs through root turnover do not necessarily equal $\mathrm{CO}_{2}$ produced by decomposition. Indeed, the relatively high $\mathrm{CO}_{2}$ production calculated for deep soil in managed pasture is inconsistent with data indicating very low fine-root biomass. The most likely explanation is decomposition of SOM derived from old, dead tree roots in the deep soils of the managed pasture. 


\section{Isotopic Content of Soil $\mathrm{CO}_{2}$}

The ${ }^{14} \mathrm{C}$ content of $\mathrm{CO}_{2}$ in the soil atmosphere provides a sensitive indicator of the relative importance of $\mathrm{CO}_{2}$ production from recently fixed $\mathrm{C}$ (which includes root respiration plus rapid decomposition of root exudates and labile organic matter) and decomposition of older organic matter [Dörr and Münnich, 1986]. $\mathrm{CO}_{2}$ derived from recently fixed $\mathrm{C}$ will have $\Delta^{14} \mathrm{C}$ close to $+143 \%$, the 1992 atmospheric $\mathrm{CO}_{2}$ value, while that derived from older organic matter will be depleted or enriched in ${ }^{14} \mathrm{C}$ relative to the 1992 atmosphere. Figure $3 \mathrm{~b}$ shows the average forest and degraded pasture profiles of $\Delta^{14} \mathrm{C}$ values from soil $\mathrm{CO}_{2}$ measured at five different times in 1992-1993. We observed no significant difference in $\Delta^{14} \mathrm{CO}_{2}$ between wet and dry seasons at depths greater than $100 \mathrm{~cm}$. Preliminary data from managed pasture (Figure $3 \mathrm{~b}$ ) show ${ }^{14} \mathrm{CO}_{2}$ profiles similar to those of forest and degraded pasture. $\Delta^{14} \mathrm{CO}_{2}$ values increase from close to 1992 atmospheric values in the upper meter to between +160 and $+170 \%$ in the deeper forest soil. A similar, though slightly smaller, increase is observed in the degraded pasture ${ }^{14} \mathrm{CO}_{2}$ values with depth. The observed $\Delta^{14} \mathrm{CO}_{2}$ increases are only possible if the majority of $\mathrm{CO}_{2}$ produced at depth in the soil results from decomposition of carbon originally fixed between 1963 and about 1990 . If we assume $50 \%$ of the $\mathrm{CO}_{2}$ produced at depth is root respiration with a $\Delta^{14} \mathrm{C}$ value of $+145 \%$, the average $\Delta^{14} \mathrm{C}$ of $\mathrm{CO}_{2}$ produced from organic matter decomposition is between +175 and $+185 \%$. This is higher than the measured ${ }^{14} \mathrm{C}$ values for fine roots at this depth $(+137 \%$ ) or the unfractionated dense soil organic matter with roots removed (averaging -800\%o). Hence decomposition of some component of the dense soil organic matter, with turnover times of several years to several decades, is producing $\mathrm{CO}_{2}$ at depths $>1 \mathrm{~m}$.

Figure $3 \mathrm{c}$ compares averaged $8^{13} \mathrm{C}$ values of soil $\mathrm{CO}_{2}$ in forest and degraded pasture soils. The degraded pasture soil $\mathrm{CO}_{2}$ signature is a mixture of $\mathrm{C} 3$ and $\mathrm{C} 4$-derived $\mathrm{CO}_{2}$. Sources of $\mathrm{CO}_{2}$ with a $\mathrm{C} 3$ signature in the degraded pasture may be from root respiration of $\mathrm{C} 3$ plants or from decomposition of older, forestderived soil organic matter. The apparent contribution of $\mathrm{C} 4$ carbon at 5-8 meters depth (where there are presumably very few roots from grasses) cannot at present be explained. One potential source would be transport of dissolved organic matter with predominately $\mathrm{C} 4$ signature from surface soil layers. Preliminary data from the managed pasture are also shown (one sampling date only). The influence of $\mathrm{C} 4$ plants is more pronounced in the upper 1-3 $\mathrm{m}$ of soil; ${ }^{13} \mathrm{C}$ values at depth indicate the presence of $\mathrm{CO}_{2}$ derived from decomposing $\mathrm{C} 3$ material.

\section{Modeling to Predict Changes in Soil Carbon with Land Use}

Qualitative conclusions based on the discussion above point to (1) rapid turnover of much of the carbon in the upper meter of tropical forest soil, and (2) turnover of some portion of the carbon below $1 \mathrm{~m}$ on annual to decadal timescales. A model of soil carbon dynamics is required for more quantitative predictions. To calculate the evolution of ${ }^{14} \mathrm{C}$ in soil $\mathrm{CO}_{2}$ and soil organic matter in steady state forest soils since 1950 , we adopt a threepool conceptual model for soil organic matter based on that used in the Century model [Parton et al., 1987; Schimel et al., 1994], and recognizing that three pools is the minimum number necessary to describe the observed soil properties of $\mathrm{CO}_{2}$ flux, change in inventory on disturbance, and ${ }^{14} \mathrm{C}$ characteristics [Schimel et al., 1994; Townsend et al., 1995]. This model has been described in detail elsewhere [Trumbore 1993; Townsend et $a l ., 1995]$ and is briefly summarized here. The active $C$ pool, with turnover times of 1-3 years, includes detrital plant material (SOM with density $<2 \mathrm{~g} \mathrm{~cm}^{3}$, including dead root biomass and, in

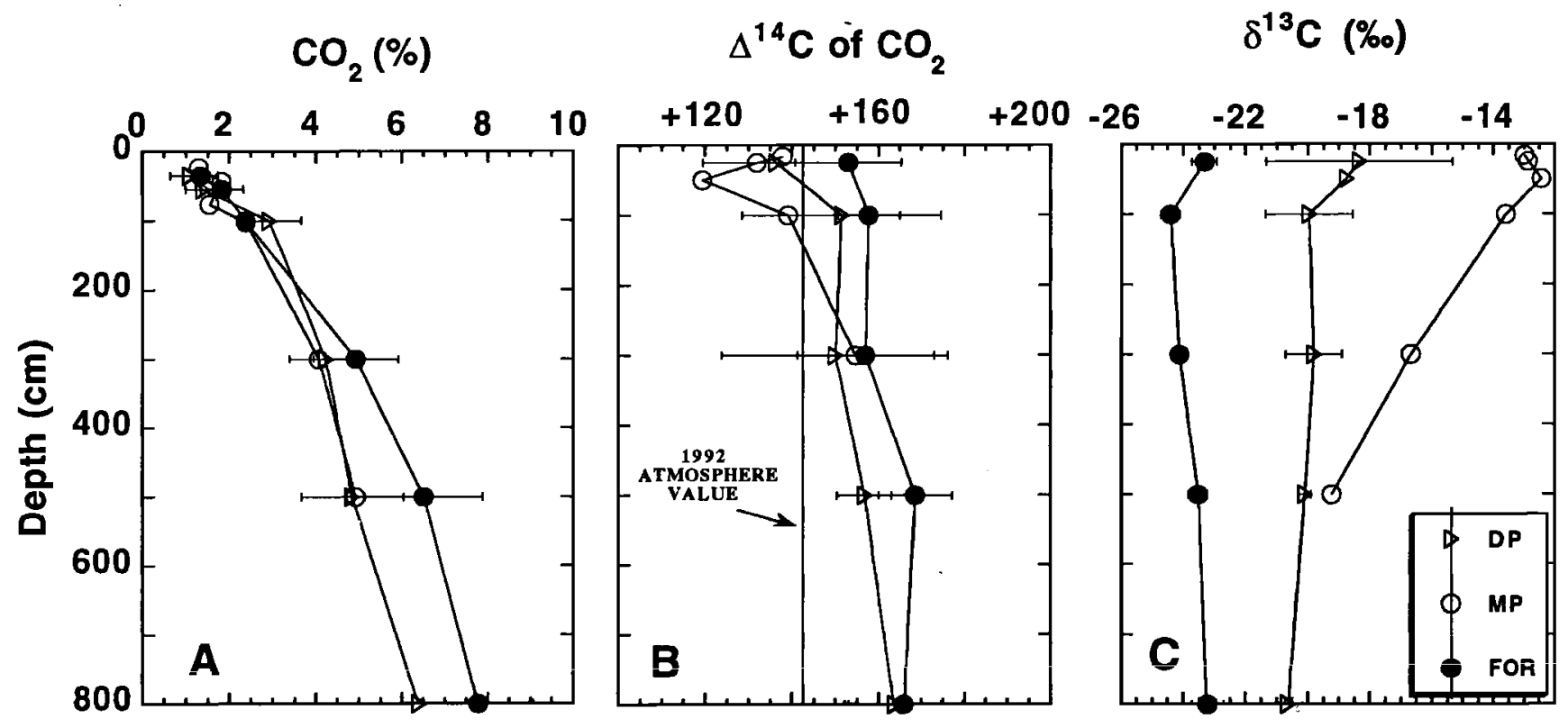

Figure 3. Average (a) concentration $\left(\% \mathrm{CO}_{2}\right),(\mathrm{b}) \Delta^{14} \mathrm{C}$, and (c) $\delta^{13} \mathrm{C}$ of $\mathrm{CO}_{2}$ in the soil atmosphere of forest (F), degraded pasture (DP) sites. Error bars represent standard deviation of the means calculated from multiple observations (up to five) at each site. Preliminary data are also shown for managed pasture (MP) for comparison. MP data are based on one measurement only, therefore do not have error bars. 
the upper $10 \mathrm{~cm}$, leaf fragments) and any component of the $>2 \mathrm{~g}$ $\mathrm{cm}^{3}$ SOM with 1-year turnover time, such as microbial biomass. The other two SOM pools include components of the $>2 \mathrm{~g} \mathrm{~cm}^{3}$ fraction of SOM with turnover times of years to decades (slow pool) and centuries to millennia (passive pool).

One constraint on the apportioning of $\mathrm{C}$ among these pools is the overall flux of $\mathrm{C}$ derived from decomposition. The annual flux of carbon from each pool is obtained by dividing the amount of carbon in the pool by its assigned turnover time. In a steady state system, total carbon inputs from litter and root turnover equal total carbon losses. A second constraint is the ${ }^{14} \mathrm{C}$ content of soil organic matter in 1992 . The carbon added annually to each soil organic matter pool is presumed to have the ${ }^{14} \mathrm{C}$ content of atmospheric $\mathrm{CO}_{2}$ observed in the southern hemisphere for that year [Manning and Melhuish, 1994]; that is, $C$ is added to detrital and other $C$ pools within a year of being fixed from the atmosphere. The passive pool is assumed to have $\Delta^{14} \mathrm{C}$ values equal to the $\Delta^{14} \mathrm{C}$ of the acid-base-acid hydrolysis residue for a given soil layer and turnover times long enough so that no bomb ${ }^{14} \mathrm{C}$ is incorporated over the past 30 years. Model pool sizes and the turnover time of the slow pool are adjusted until $1992{ }^{14} \mathrm{C}$ values for soil organic matter and decomposition-derived $\mathrm{CO}_{2}$ generated by the model match observed values (assuming total respired $\mathrm{CO}_{2}$ is $50 \pm 10 \%$ root respiration with $\Delta^{14} \mathrm{C}$ of that year's atmospheric $\mathrm{CO}_{2}$ ) and fluxes match observed inputs and outputs of carbon (Table 3).

\section{Steady State: Carbon Fluxes in Mature Forest Solls}

The $\Delta^{14} \mathrm{C}$ observed in mineral-associated $\left(>2 \mathrm{~g} \mathrm{~cm}^{3}\right)$ organic matter is strongly influenced by how much passive organic matter is present. Passive pools, in which $\mathrm{C}$ resides for a long time compared to the rate of radiodecay of ${ }^{14} \mathrm{C}$, will act to "dilute" the ${ }^{14} \mathrm{C}$ in more rapidly cycling pools. Figure 4 shows the sensitivity of model-predicted $1992 \Delta^{14} \mathrm{C}$ of bulk soil organic matter to the amount of passive pool and its presumed $\Delta^{14} \mathrm{C}$ value. The measured ${ }^{14} \mathrm{C}$ content of organic matter for soil depths of $0-10,10-100$, and $300-500 \mathrm{~cm}$ are shown as horizontal lines, which identify the possible range of allowed passive-pool characteristics. Chemical fractionation of SOM in the upper 100 $\mathrm{cm}$ of soil (Table 2) shows residues after acid-base-acid hydrolysis that range in ${ }^{14} \mathrm{C}$ content from those containing bomb carbon (top $2.5 \mathrm{~cm}$ ) to those essentially ${ }^{14} \mathrm{C}$-free $(100 \mathrm{~cm})$. We use the $\mathrm{C}$ inventory-weighted average of the nonhydrolyzable residue for each depth interval as the minimum estimate of the ${ }^{14} \mathrm{C}$ content of the passive fraction. These values, derived from Table 2 forest data and shown on Figure 4, are $-250 \%$ for $0-10$ $\mathrm{cm},-450 \%$ for $10-100 \mathrm{~cm}$, and $-993 \%$ for layers deeper than 100 $\mathrm{cm}$. Assuming the $\Delta^{14} \mathrm{C}$ values reflect mean residence times for the passive pool, these values correspond to turnover times of 2700,6000 and 100,000 years, respectively [Trumbore et al., 1992]. Figure 4 demonstrates that regardless of the presumed $\Delta^{14} \mathrm{C}$ value passive-pool abundances must range from about 10 $25 \%$ of the total soil organic matter in the $0-10 \mathrm{~cm}$ soil layer to $\geq$ $90 \%$ in the deep soil $(>300 \mathrm{~cm})$.

The magnitude of the annual flux of carbon entering and leaving the soil and the carbon isotopic composition of $\mathrm{CO}_{2}$ produced from decomposition are sensitive to the partitioning of nonpassive carbon into active and slow pools. If we assume that $\mathrm{C}$ in the deep soil layers is $90 \%$ passive, the consequences of distributing the remaining $10 \%$ of the total soil carbon between

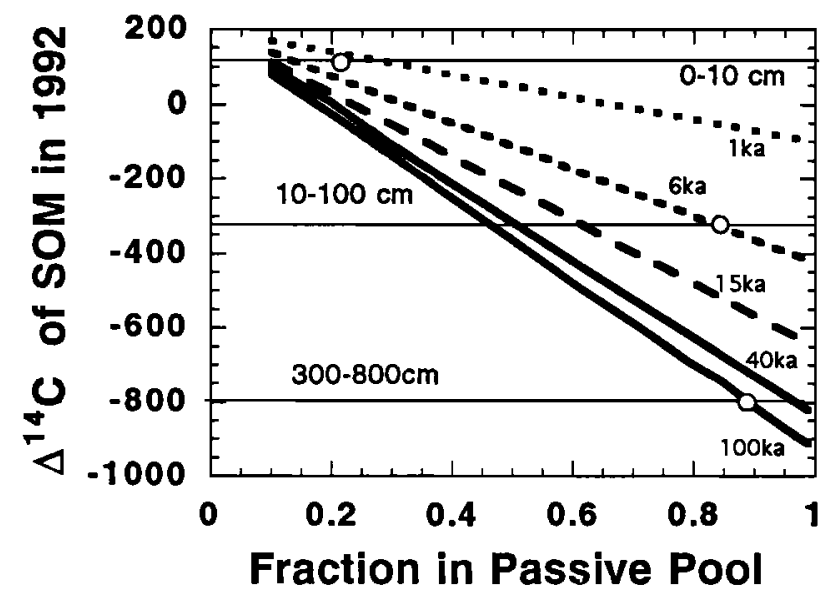

Figure 4. Sensitivity of modeled $1992 \Delta^{14} \mathrm{C}$ values for dense fraction forest soil organic matter to the amount and turnover time of the passive pool. The model described in the text was used to calculate the $1992{ }^{14} \mathrm{C}$ content of soil organic matter which was comprised of $10-100 \%$ passive pool carbon ( $x$ axis). The different curves were calculated assuming turnover times for the passivepool carbon, which varied from 1,000 to 100,000 years, as identified. The remaining (nonpassive) carbon was presumed to have a turnover time of 20 years; the sensitivity of the 1992 radiocarbon to this assumption (as opposed to assuming mixtures of annual and decadal pools) only becomes important when the amount of passive carbon is $<20 \%$. Horizontal lines show the measured $\Delta^{14} \mathrm{C}$ value for $0-10,10-100$, and $300-800 \mathrm{~cm}$ forest soil organic matter. Intersections of the model curves and horizontal lines define the possible range of passive carbon amount and turnover time for each depth. Circles show the $\Delta^{14} C$ of nonhydrolyzable dense organic matter for the same depth intervals (used to constrain the passive fraction $\Delta^{14} \mathrm{C}$ in modeling).

the active (1-year turnover) and slow pools on predicted carbon fluxes and on the ${ }^{14} \mathrm{C}$ content of decomposition-derived $\mathrm{CO}_{2}$ are shown in Figures $5 a$ and $5 b$. The $x$ axes in these figures fix the amount of carbon in the active pool (the slow-pool carbon abundance is then $10 \%$ minus this number), and the results are shown for a range of slow-pool turnover times (5 to 75 years). Crosshatched regions show the range of observed values of flux from Table 3 (expressed as a fraction: $\mathrm{g} \mathrm{C} \mathrm{m}^{-2} \mathrm{yr}^{-1}$ flux per $\mathrm{kgC}$ in the depth interval) and $\Delta^{14} \mathrm{CO}_{2}$ for the deep soil. The stippled region on Figure $5 \mathrm{~b}$ shows the range of values that match both the predicted $\mathrm{CO}_{2}$ flux and ${ }^{14} \mathrm{C}$ content of respired $\mathrm{CO}_{2}$. Thus active $\mathrm{C}$ is constrained to be $\mathbf{0 . 5 - 0 . 9 \%}$ and slow $\mathrm{C}$ about $9.3 \%$ of the total carbon in this layer. The slow-pool turnover time must be 15-25 years. Attempts to model with greater amounts of passive C (>90\%) cannot reproduce all three observed variables of carbon flux, $1992{ }^{14} \mathrm{CO}_{2}$, and 1992 soil organic matter ${ }^{14} \mathrm{C}$ content simultaneously.

This same approach is applied to depth intervals of 10-100 and $100-300 \mathrm{~cm}$. Figure 6 depicts $\mathrm{C}$ fluxes associated with the mature forest soil, and Table 4 summarizes the model parameters which provide the best match to the observational constraints of carbon inputs, soil organic matter ${ }^{14} \mathrm{C}$, and ${ }^{14} \mathrm{CO}_{2}$. Partitioning of carbon in the upper meter reflects the uncertainty in the assumed 

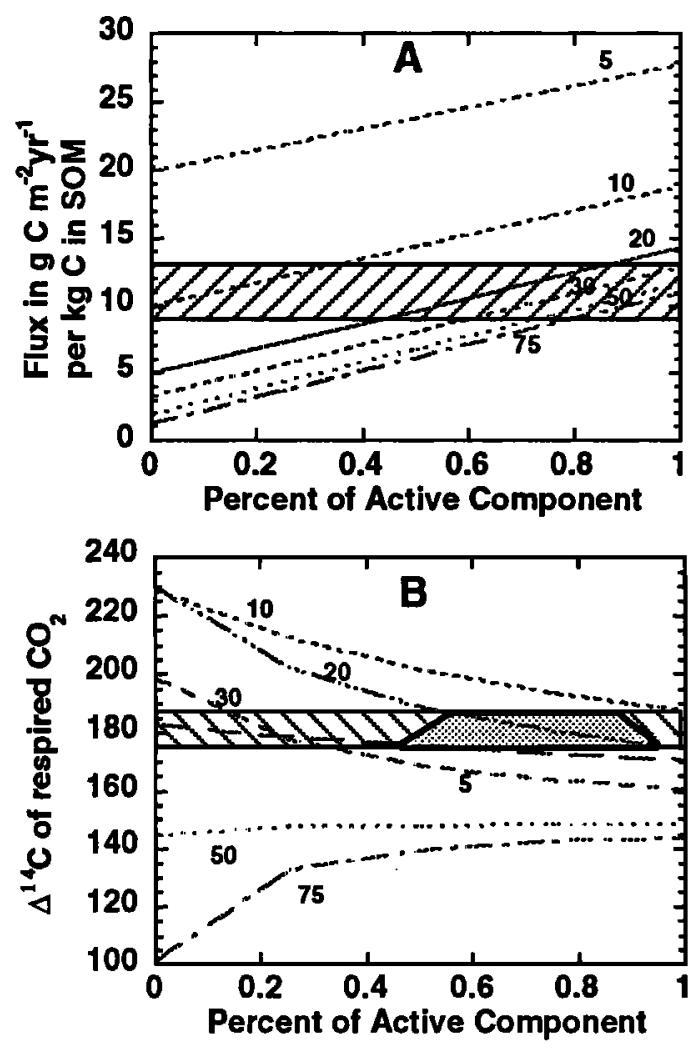

Figure 5. Sensitivity of (a) model-calculated $\mathrm{CO}_{2}$ flux and (b) the $\Delta^{14} \mathrm{C}$ of $\mathrm{CO}_{2}$ derived from decomposition of dense forest soil organic matter in 1992 to the apportioning of carbon among active (1-year turnover) and slow (turnover times of 5,10,20,30, 50, and 75 years) pools. These are calculated assuming that $90 \%$ of the SOM is in the passive pool $(100,000$-year turnover time, or $\Delta^{14} \mathrm{C}$ of $-990 \%$ ), which can be applied to the $300-800 \mathrm{~cm}$ SOM. The crosshatched areas show the range of measured root biomass (flux assumes 1 year turnover, here normalized per $\mathrm{kg}$ of carbon in SOM) and $\Delta^{14} \mathrm{CO}_{2}$, assuming that $50 \pm 10 \%$ of the soil atmosphere $\mathrm{CO}_{2}$ is root respiration. The only subset of model parameters which fit both flux and $\Delta^{14} \mathrm{CO}_{2}$ constraints are identified by the stippled area in Figure 5 b.

${ }^{14} \mathrm{C}$ content of the passive-pool carbon (derived from fractionation ${ }^{14} \mathrm{C}$ data). If the ${ }^{14} \mathrm{C}$ content of the passive pool is decreased from $-450 \%$ to $-993 \%$ in the $10-100 \mathrm{~cm}$ layer, the amount of $\mathrm{C}$ in the slow pool would decrease from 56 to $18 \%$, and turnover times in the slow pool would decrease from 25-35 years to 15-25 years (Table 4). Hence the ranges of estimates shown in Table 4 are often large. We use values based on the measured passive-pool $\Delta^{14} \mathrm{C}(-450 \%)$ for modeling changes in $\mathrm{C}$ accompanying land use change (below).

Active $C$ in the $0-10 \mathrm{~cm}$ soil layer is assumed to equal the $C$ inventory found in the vascular plant matter in the low-density fraction ( $30 \%$ of the total soil C). The $1992 \Delta^{14} \mathrm{C}$ value for this material is consistent with either a single homogeneous pool with turnover times of 2-3 years or a mixture of $0-10 \% \mathrm{C}$ with 1 year turnover and $90-100 \%$ slow carbon with a turnover time of 3.5 to 4 years (no passive pool). The steady state carbon flux associated with just the low density portion of SOM is thus $210 \mathrm{~g} \mathrm{C} \mathrm{m}^{-2} \mathrm{yr}^{-1}$
Forest (steady state)

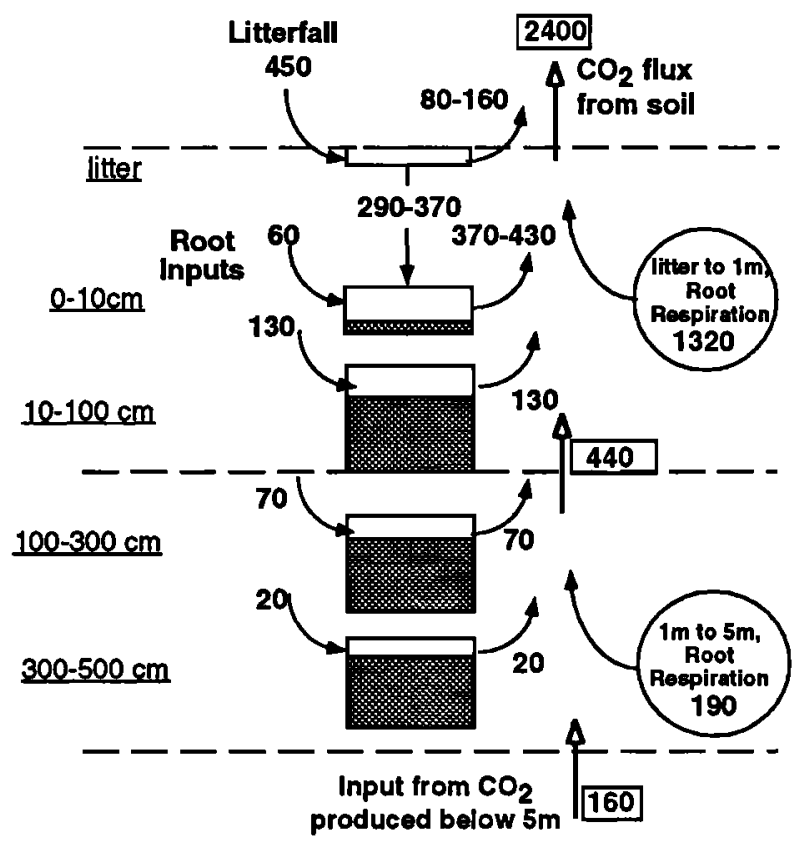

Figure 6. Summary of belowground carbon cycling derived from measurements and modeling. Fluxes are in $\mathrm{g} \mathrm{C} \mathrm{m}^{-2} \mathrm{yr}^{-1}$. The boxes represent bulk soil organic matter; shading shows the relative proportion of passive SOM for each depth interval. Carbon inputs are taken from fine-root biomass estimates (Table 3); forest carbon outputs are assumed to equal $\mathrm{C}$ inputs (steady state system). The total amount of $\mathrm{CO}_{2}$ produced in the litter- $1 \mathrm{~m}$ and $1 \mathrm{~m}$ to $5 \mathrm{~m}$ soil layers are taken from Davidson and Trumbore [1995], as is the estimated production below $500 \mathrm{~cm}$. Transfers of $\mathrm{C}$ from the litter to upper soil layer are discussed in the text.

( $720 \mathrm{~g} \mathrm{C} \mathrm{m}^{-2}$ per 3.5 years) to $230 \mathrm{~g} \mathrm{C} \mathrm{m}^{-2} \mathrm{yr}^{-1}\left(72 \mathrm{~g} \mathrm{C} \mathrm{m}^{-2}\right.$ per 1 year $+648 \mathrm{~g} \mathrm{C} \mathrm{m}^{-2}$ per 4 years). The remaining $70 \%$ of the organic matter in the $0-10 \mathrm{~cm}$ layer is associated with mineral particles (density $>2.0 \mathrm{~g} \mathrm{~cm}^{-3}$; Table 2). The partitioning of carbon among pools which best matches the observed ${ }^{14} \mathrm{C}$ values

Table 4. Bestfit Parameters for Modeling Forest Soil Organic Matter

\begin{tabular}{|c|c|c|c|c|c|c|}
\hline \multirow{2}{*}{$\begin{array}{l}\text { Depth } \\
\text { Range }\end{array}$} & \multicolumn{2}{|c|}{ Active } & \multicolumn{2}{|c|}{ Slow } & \multicolumn{2}{|c|}{ Passive } \\
\hline & $\% \mathrm{C}_{\mathrm{T}}$ & TT & $\% \mathrm{C}_{\mathrm{T}}$ & TT & $\% \mathrm{C}$ & $\Delta^{14} \mathrm{C}$ \\
\hline $0-10 \mathrm{~cm}$ & 30 & 3 & $60-65$ & $10-30$ & $5-10$ & $<-250 \%$ \\
\hline $10-100 \mathrm{~cm}$ & 2 & 1 & $18-56$ & $15-35$ & $42-80$ & $<-450 \%$ \\
\hline $100-300 \mathrm{~cm}$ & 1 & 1 & $14-19$ & $20-25$ & $80-85$ & $-993 \%$ \\
\hline $300-500 \mathrm{~cm}$ & 0.7 & 1 & 9.3 & $15-25$ & 90 & $-993 \%$ \\
\hline
\end{tabular}

Active $\mathbf{C}$ is detrital plant material plus microbial biomass. In the $\mathbf{0}$ $10 \mathrm{~cm}$ layer the values given are for the low-density organic matter fraction, which has ${ }^{14} \mathrm{C}$ consistent with 3 year turnover. Active $\mathrm{C}$ pools deeper than this are assumed to have 1-year turnover. $\% \mathrm{C}_{\mathrm{T}}$ per cent of total soil carbon in pool; TT, turnover time in years. $\Delta^{14} \mathrm{C}$ is given for passive fraction (see text for equivalent turnover times). 
for this fraction, assuming the passive fraction is $12-14 \%$ of the carbon and has a $\Delta^{14} \mathrm{C}$ of $-250 \%$ (Table 2 ), $1-3 \%$ is in the active pool ( 1 year turnover), and $82-84 \%$ in the slow pool (10-12 year turnover). The steady state flux predicted through this fraction is thus $160-200 \mathrm{~g} \mathrm{C} \mathrm{m}^{-2} \mathrm{yr}^{-1}$.

The combined annual flux required to support the presence of all the bomb ${ }^{14} \mathrm{C}$ in the $0-10 \mathrm{~cm}^{2}$ layer $\left(210-230 \mathrm{~g} \mathrm{C} \mathrm{m}^{-2} \mathrm{yr}^{-1}\right.$ for the low density plus $160-200 \mathrm{~g} \mathrm{C} \mathrm{m}^{-2} \mathrm{yr}^{-1}$ for the dense fraction, or $370-430 \mathrm{~g} \mathrm{C} \mathrm{m}^{-2} \mathrm{yr}^{-1}$ ) is much greater than the estimated input of carbon from fine root biomass $\left(-60 \mathrm{~g} \mathrm{C} \mathrm{m}^{-2} \mathrm{yr}^{-1}\right.$; Table 3). This discrepancy is not found for deeper soil layers. One source of additional $C$ inputs to the $0-10 \mathrm{~cm}$ soil layer is from the overlying litter layer (with annual carbon inputs of $460 \mathrm{~g} \mathrm{C} \mathrm{m}^{-2}$ ), either through bioturbation (for low density materials) or through sorption of downward-percolating dissolved organic carbon. Pieces of leaf matter are seen in the low density fraction, and insects commonly transport surface detritus into the mineral soil. Alternatively, the presence of organs (organic coatings) on aggregates in this layer supports the hypothesis of transport involving dissolved organic carbon.

\section{Nonsteady State : Prediction of Response to Disturbance}

The $\mathrm{C}$ budget outlined in Figure 6, when combined with the partitioning of SOM into active, slow, and passive pools as shown in Table 4, may be used in a dynamic model to predict how carbon inventories will change in response to a perturbation in carbon inputs, such as that which accompanies a change from forest to pasture vegetation. To predict pasture carbon inventory and isotopic content, we ran the forest model but changed the amount and depth distribution of carbon inputs by litter and roots in 1969. We combined $0-10 \mathrm{~cm}$ and $10-100 \mathrm{~cm}$ depth intervals assuming a linear bulk density change between 1969 and 1992 for the pasture soils (so that we weight $0-10 \mathrm{~cm}$ as $0-8 \mathrm{~cm}$ in 1992). We assumed that $C$ inputs in degraded pastures initially were higher than the forest then dropped to about $65 \%$ of forest values by 1992 (see Table 5 for details). The modeled managed pasture had inputs equal to those of the degraded pasture between 1969 and 1987, after which time values increased to 3 and 4 times those of the forest in $0-10 \mathrm{~cm}$ and $10-100 \mathrm{~cm}$ depth intervals, respectively. $C$ inputs below $100 \mathrm{~cm}$ are assumed to be constant in degraded pastures, while managed pasture values drop in 1987 to one third of forest values in the $100-300 \mathrm{~cm}$ interval, and to one tenth of forest values for $300-800 \mathrm{~cm}$.

The predicted evolution of soil carbon inventory, $\Delta^{14} \mathrm{C}$, and $\delta^{13} \mathrm{C}$ in the upper meter of mature forest, degraded pasture, and managed pasture soils since 1969 are compared with observed 1992 values in Figures $7 \mathrm{a}$ to $7 \mathrm{c}$. Changes in carbon inventory and rates of $\mathrm{C}$ gain or loss as of 1992 are summarized in Table 5. The model predicts the loss of roughly $0.9 \mathrm{~kg} \mathrm{C} \mathrm{m}^{-2}$ between 1969 and 1992 from the upper meter of the degraded pasture soil, which is larger than the change reported in Table 1 but less than the minimum detectable difference in carbon inventory in the 0 $100 \mathrm{~cm}$ depth range. The modeled ${ }^{14} \mathrm{C}$ values, which are more sensitive to demonstrating the loss of modern carbon from the pasture soil, are in accord with data from the degraded pasture (Figure 7b). Initial rates of carbon loss in 1969 were high, up to $100 \mathrm{~g} \mathrm{C} \mathrm{m}^{-2} \mathrm{yr}^{-1}$, but had slowed in 1992 to net loss of $40 \mathrm{~g} \mathrm{C}$ $\mathrm{m}^{-2} \mathrm{yr}^{-1}$ (see summary in Table 5). Changes in $\delta^{13} \mathrm{C}$ of degraded
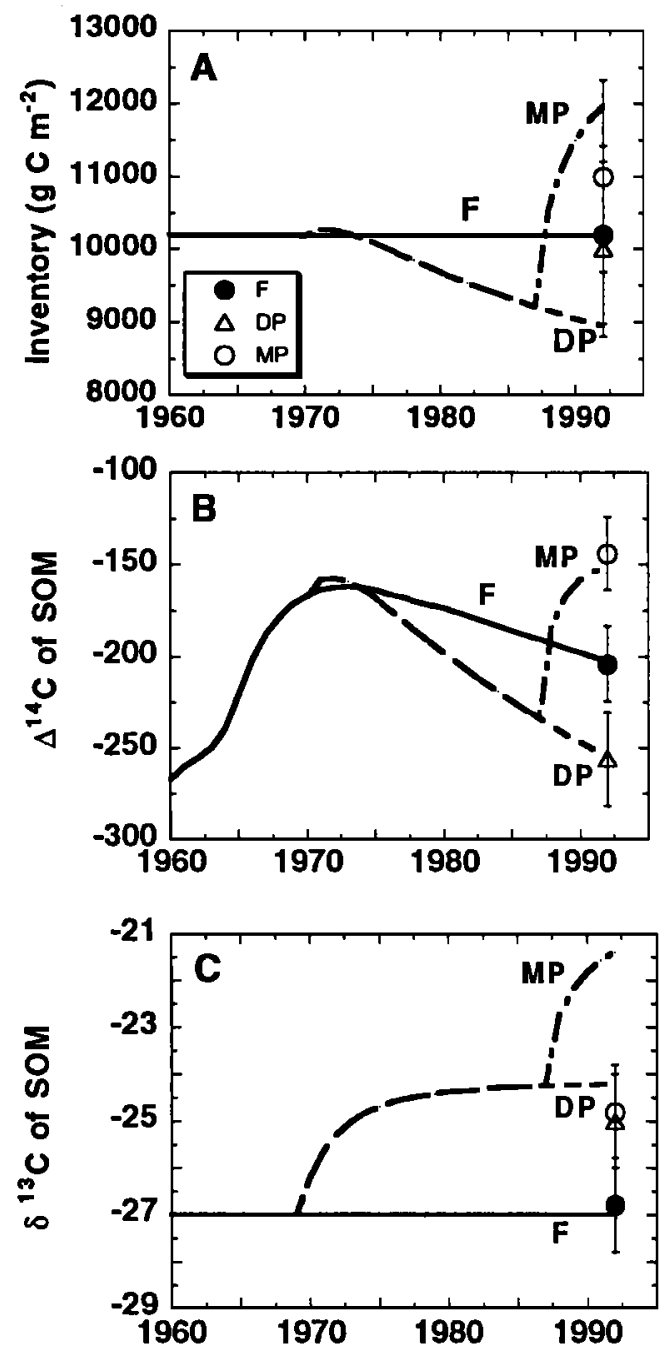

Figure 7. Changes in (a) carbon inventory, (b) the $\Delta^{14} \mathrm{C}$ of bulk SOM, and (c) $\delta^{13} \mathrm{C}$ of bulk SOM in the upper meter of soil predicted by the model for different types of pasture management following deforestation. We assume carbon inputs in newly formed pasture in 1970 were 1.3 times that of the original forest, dropping with time as the pasture degrades to 0.64 times forest inputs by 1992. Managed pastures were assumed to follow the same pattern of $C$ inputs until 1988, when application of phosphorous fertilizer increased $\mathrm{C}$ inputs to the soil to 3-4 times forest inputs. The model parameters partitioning carbon into active, slow, and passive pools are those given in Tables 4 and 5 . Data from degraded and managed pasture and forest sites measured in 1992 are shown. F, forest; DP, degraded pasture; MP, managed pasture

pasture soil organic matter (Figure 7c) are also in accord with model predictions, assuming $80 \%$ passive $C$ with $\Delta^{14} \mathrm{C}$ of $-450 \%$. However, if we assume only $45 \%$ of the carbon in the $10-100 \mathrm{~cm}$ depth interval is passive (Table 4), the model would over-predict the observed ${ }^{13} \mathrm{C}$ values.

The managed-pasture scenario predicts sequestering of significant amounts of carbon in the upper meter of the soil $(-1.2$ $\mathrm{kg} \mathrm{C} \mathrm{m}^{-2}$ greater than the original forest inventory in 1992, but 
Table 5. Predicted Changes in C Inventory and Flux with Management

\begin{tabular}{lrr}
\hline & DP & DP+MP \\
\hline $0-100 \mathrm{~cm}$ & \\
1969 to $1992\left(\mathrm{~g} \mathrm{C} \mathrm{m}^{-2}\right)$ & -870 & +2560 \\
$1992 \mathrm{C}$ inputs $\left(\mathrm{g} \mathrm{C} \mathrm{m}^{-2} \mathrm{yr}^{-1}\right)$ & 360 & 1620 \\
$1992 \mathrm{CO}_{2}$ produced $\left(\mathrm{g} \mathrm{C} \mathrm{m}^{-2} \mathrm{yr}^{-1}\right)$ & 400 & 1370 \\
1992 net $\mathrm{C}$ change $\left(\mathrm{g} \mathrm{C} \mathrm{m}^{-2} \mathrm{yr}^{-1}\right)$ & -40 & +250 \\
$100-300 \mathrm{~cm}$ & & \\
1969 to $1992\left(\mathrm{~g} \mathrm{C} \mathrm{m}^{-2}\right)$ & 0 & -330 \\
1992 net $\mathrm{C}$ change $\left(\mathrm{g} \mathrm{C} \mathrm{m}^{-2} \mathrm{yr}^{-1}\right)$ & 0 & -50 \\
$300-800 \mathrm{~cm}$ & 0 & -200 \\
1969 to $1992\left(\mathrm{~g} \mathrm{C} \mathrm{m}^{-2}\right)$ & 0 & -30 \\
1992 net $\mathrm{C}$ change $\left(\mathrm{g} \mathrm{C} \mathrm{m}^{-2} \mathrm{yr}^{-1}\right)$ & & \\
$0-800 \mathrm{~cm}$ & & \\
1969 to $1992\left(\mathrm{~g} \mathrm{C} \mathrm{m}^{-2}\right)$ & -930 & +2030 \\
1992 net $\mathrm{C}$ change $\left(\mathrm{g} \mathrm{C} \mathrm{m}^{-2} \mathrm{yr}^{-1}\right)$ & -10 & +170 \\
\hline
\end{tabular}

DP, degraded pasture starting in 1969 and continuing to the present; DP+MP, same as degraded pasture between 1969 and 1988, then managed pasture. Estimates are based on assuming $C$ inputs vary as a fraction of forest $C$ inputs $(F)$ using the following relations: for degraded pasture, $F=0.6+0.7 \times \exp [-.15 \times$ (year - 1970)]; for managed pasture, the degraded pasture equation is used until 1988 when $F$ is increased to 4 (and remains constant for 1988-1992).

nearly $2 \mathrm{~kg} \mathrm{C} \mathrm{m}^{-2}$ greater than the degraded pasture). Carbon losses below $100 \mathrm{~cm}$ in the soil due to the loss of root $C$ inputs after 1987 offset nearly half the total carbon gained (since 1969) in the upper meter (see Table 5). Large amounts of $C$ are sequestered in soils following the first year after pasture reformation ( $\left.+0.8 \mathrm{~kg} \mathrm{C} \mathrm{m}^{-2} \mathrm{yr}^{-1}\right)$, and the managed pasture soil remains a net $C$ sink of nearly $0.2 \mathrm{~kg} \mathrm{C} \mathrm{m}^{-2}$ in 1992 . However, Figure $7 \mathrm{c}$ shows that the model overpredicts ${ }^{13} \mathrm{C}$ increases in managed pasture. Some of this increase may be explained by the removal of roots by sieving during preparation of samples for ${ }^{13} \mathrm{C}$ analysis, which would tend to make the measured ${ }^{13} \mathrm{C}$ heavier than an analysis which included the plant detritus (mostly $\mathrm{C} 4$ in the upper meter). A second reason could be differences in the character of the degraded pasture which preceeded pasture reformation.

The model of carbon cycling for tropical forest soils developed here provides an approach to predicting the changes in soil carbon storage with land management in tropical soils of the type found near Paragominas. Other studies of $\mathrm{C}$ turnover in tropical soils, restricted to the upper $20 \mathrm{~cm}$ of the soil, show dynamics similar to those in this study over the same depth interval [Trumbore, 1993; Veldkamp, 1994; Townsend et al., 1995]. If changes in carbon inputs as a function of depth are known, carbon inventories in the fast-cycling components of soil organic matter will adjust accordingly to new steady state values. For soils at Fazenda Victoria, it would take approximately 50 years to reach a new steady state, although rates of change would be small after 10 years (Table 5). Our approach to modeling $C$ inventory changes with land use could be improved by including changes in vegetation productivity with time (and perhaps feedbacks between SOM dynamics and plant productivity).

Figure $7 \mathrm{~b}$ shows the utility of ${ }^{14} \mathrm{C}$ as a more sensitive indicator of changes in carbon stocks over the past $\mathbf{3 0}$ years than inventory measurements. The differences in carbon stocks between forest and degraded pasture are not significant given the errors in bulk density and \%C measurements, while changes in ${ }^{14} \mathrm{C}$ are significant. Pastures which are sequestering carbon should have higher ${ }^{14} \mathrm{C}$ contents, while pastures losing carbon at the surface should have significantly lower ${ }^{14} \mathrm{C}$ than the undisturbed forest. Changes in deep soil carbon are more subtle, as neither the changes in carbon inventory nor the changes in ${ }^{14} \mathrm{C}$ content predicted by the models for the deep soil are above detection limits. Measurements of $\mathrm{CO}_{2}$ production and the ${ }^{14} \mathrm{C}$ content of deep-soil $\mathrm{CO}_{2}$ (still underway at managed pasture sites) will be more sensitive indicators of changes in the deep soil carbon cycle.

\section{Extrapolation to Other Parts of Amazonia}

Our measurement of annual soil respiration in mature forest ( $2400 \mathrm{~g} \mathrm{C} \mathrm{m}^{-2} \mathrm{yr}^{-1}$ ) is high relative to most values reported in the literature [Raich and Nadelhoffer, 1989; Raich and Schlesinger, 1992]. In a review of data from boreal, temperate, and tropical forests, Raich and Nadelhoffer [1989] found that total soil respiration correlated with litterfall $C$, and that total belowground $\mathrm{C}$ allocation could be deduced from this relationship. Using their regression equations and our litterfall measure of $460 \mathrm{~g} \mathrm{C} \mathrm{m}^{-2}$ $\mathrm{yr}^{-1}$, we would expect only $1500 \mathrm{~g} \mathrm{C} \mathrm{m}^{-2} \mathrm{yr}^{-1}$ total soil respiration, of which $1000 \mathrm{~g} \mathrm{C} \mathrm{m}^{-2} \mathrm{yr}^{-1}$ would be due to total root allocation. Our budget (Table 3; Figure 6), which is constrained by direct measures of respiration and litterfall, as well as isotopic contents of SOM and $\mathrm{CO}_{2}$, indicates that allocation of $\mathrm{C}$ to roots must be about $1900 \mathrm{~g} \mathrm{C} \mathrm{m}^{-2} \mathrm{yr}^{-1}$, or nearly twice the estimate based on the regressions reported by Raich and Nadelhoffer [1989]. Only five studies of tropical forests met the criteria for data quality imposed by Raich and Nadelhoffer [1989], and none of these was a seasonally dry tropical forest. The Amazonian forest of our study experiences a significant water deficit during a 5-month dry season, and a zone of fine-root proliferation migrates down the soil profile as the upper horizons dry. In light of the critical role of deep roots maintaining an evergreen canopy in this seasonally dry ecosystem, it is not surprising that we estimate greater root respiration and below ground allocation of $C$ than expected based on regressions of data from other regions. Obtaining sufficient water in this environment requires a huge investment of carbon belowground.

Nepstad et al. [1994] have suggested that the entire eastern half of the closed canopy forest of Amazonia relies on deep roots to maintain an evergreen canopy throughout a prolonged dry season. We hypothesized that the fraction of net primary productivity (NPP) allocated to roots increases along the gradient of precipitation seasonality from the northwest, where there is little seasonality in precipitation, to the southeast, where the dry season can be several months. Indeed, a forest near Manaus, where the seasonality is less severe than at our study site near Paragominas, was used by Raich and Nadelhoffer [1989], and it seems to have conformed to their reported trend. We expect that other forest sites to the east and south of Manaus will show greater belowground $\mathrm{C}$ allocation. The eastern and southern flanks of the Amazon are also the areas undergoing the most rapid rates of deforestation [Nepstad et al., 1991]. An understanding of the patterns of root allocation and belowground $\mathrm{C}$ dynamics in the forests and pastures of this region is needed to assess the impacts of human activities on the global $\mathrm{C}$ budget. 
The area of total deforestation in the Amazon has been estimated to be 100,000 [Hecht, 1985; Serrao and Toledo, 1988] to $230,000 \mathrm{~km}^{2}$ [Skole and Tucker, 1993], of which $50 \%$ is estimated to be degraded pasture [Serrao and Toledo, 1988; Mattos and Uhl, 1994]. If we assume losses of carbon in degraded pastures of the order of $1 \mathrm{~kg} \mathrm{C} \mathrm{m}^{-2}$, a total of $0.05-0.1$ $\mathrm{Gt} \mathrm{C}$ may have been transferred from these degraded pasture soils to the atmosphere over the past two decades. Some of this transfer may be offset by gains in soil carbon as more productive ecosystems (secondary forests and productive grasses) replace degraded pasture. Indeed, Fisher et al. [1994] estimated that well-managed pastures of South America may be taking up as much as $0.05 \mathrm{Gt} \mathrm{C}$ annually in soils. While our data support the idea that productive grasses can cause sequestering of large amounts of $\mathrm{C}$ in soils, the Fisher et al. calculation is probably an overestimate of soil $\mathrm{C}$ gains because they did not take into account decreases in the rate of soil $\mathbf{C}$ gain as the system comes into a new steady state (see Figure 7a). In any case, transfers of $\mathrm{C}$ from biomass to the atmosphere during conversion of forests to pastures are much larger than those from soils, and changes in aboveground biomass will dominate those of soil organic matter in global carbon budgets for this type of land use change.

Townsend et al. [1992] suggest that the strong temperature dependence of decomposition rates in fast-cycling SOM pools, coupled with the large amounts of fast-cycling $C$ in tropical forest soils, could lead to large positive feedbacks between tropical forest SOM and global or regional temperature changes. The temperature dependence of turnover in tropical SOM has been documented by studying an elevation-based climate sequence on the island of Hawaii [Townsend et al., 1995]. Our study demonstrates that large amounts of SOM have fast turnover times in tropical forest soils typical of much of Amazonia. Thus significant interannual to decadal changes in net $\mathrm{C}$ fluxes to or from soil organic matter may accompany changes in climate.

\section{Conclusions}

A detailed model of the belowground carbon cycle in a seasonally dry, deep-rooting, evergreen tropical forest may be used to predict the rate of change of soil carbon following deforestation and conversion to pasture. In order to satisfy the multiple constraints of carbon flux, inventory, and isotopic content, the following must be true at this site:

1). Although on average deep-soil organic matter has low concentrations and low ${ }^{14} \mathrm{C}$ content, an active carbon cycle associated with presence of deep roots is present at depths below $1 \mathrm{~m}$. The combined carbon inventory in pools cycling at annual to decadal time scales between 100 - and $800-\mathrm{cm}$ depth in the forest soil is $2-3 \mathrm{~kg} \mathrm{C} \mathrm{m} \pi^{-2}$ (ouit of a total of $17 \mathrm{~kg} \mathrm{C} \mathrm{m}^{-2}$ ), comparian tó $3-4 \mathrm{~kg} \mathrm{C} \mathrm{m}-2$ in the top meter (total of $10-11 \mathrm{~kg} \mathrm{C} \mathrm{m}^{-2}$ )

2). Turnover of carbon in active plus slow soil organic matter pools is rapid. The carbon inventory-weighted average turnover time for active plus slow pools is $<12$ years in the upper meter of SOM and $<25$ years in the $100-800 \mathrm{~cm}$ layer, in accord with other recent work in tropical soils and with ecosystem model predictions.

A method of predicting changes in carbon inventory in soils following land use change is proposed based on assuming constant carbon dynamics in scenarios with changing carbon inputs. Our results explain why some pastures have been reported to gain soil $\mathrm{C}$ while others have lost soil $\mathrm{C}$ relative to the forests and savannas that they replace. Overgrazed degraded pastures, which dominate the landscape in cleared areas of Pará, lose soil $\mathbf{C}$ as plant productivity declines. Managed pastures have the potential to increase carbon storage in surface soils, although this increase in soil $\mathrm{C}$ due to increased root inputs in the top $1 \mathrm{~m}$ of soil would be offset partially by losses of soil $\mathrm{C}$ deeper in the soil. Maintaining grass productivity and root inputs to the soil is the key to maintaining, or even increasing, soil $\mathrm{C}$ stocks. Unfortunately, well-managed pastures are still the exception rather than the rule in eastern Amazonia. Because increases and decreases in soil $\mathrm{C}$ stocks can occur within years to decades as a result of land use change in tropical zones, management is an important factor in determining the effects of land use change on the global $\mathrm{C}$ budget.

Acknowledgments. We thank Paulo Moutinho and José Henrique Cattanio of the Instituto de Pesquisa Ambiental da Amazonia and Paul Lefebvre of the Woods Hole Research Center for help with field work and logistics. We also thank Zheng Shuhui for sample preparation at UC Irvine, and John Southon, Michaele Kashgarian, and Jay Davis at the Center for AMS, Lawrence Livermore National Laboratory for help with ${ }^{14} \mathrm{C}$ analyses. The manuscript benefitted greatly from 3 anonymous reviews. This research was supported by grants from the NASA Mission to Planet Earth program (NASA NAGW-2748, NAGW-2750, and NAGW-3748) and the National Science Foundation (BSR-9119835, to Nepstad). Davidson, Trumbore, and Nepstad also acknowledge support from the A. W. Mellon Foundation. Camargo and Martinelli were supported by FAPESP grant 92/4169-1.

\section{References}

Balesdent, J., A. Mariotti, and B. Guillet, Natural ${ }^{13} \mathrm{C}$ abundance as a tracer for studies of soil organic matter dynamics, Soil Biol. Biochem. 19, 25-30, 1987.

Bauer, J., P. M. Williams, and E. R. M. Druffel, Recovery of submilligram quantities of carbon dioxide from gas streams by molecular sieve for subsequent determination of isotopic natural abundance, Anal.Chem. 64, 824-827, 1992.

Böhm, W., Methods of Studying Root Systems, Springer-Verlag, New York, 1979.

Bowden, R. D., K. J. Nadelhoffer, R. D. Boone, J. M. Melillo, and J. B. Garrison, Contribution of aboveground litter, belowground litter, and root respiration to total soil respiration in a temperate mixed hardwood forest, Can.J.For.Res., 23, 1402-1407, 1993.

Cerri, C. C., B. P. Eduardo, and M. C. Piccolo, Use of stable isotopes in soil organic matter studies, in Stable lsotopes in Plant Nutrition, Soil Fertility and Environmental Studies, pp. 247-259, Int. At. Energy Agency, Vienna, Austria, 1991.

Chone, T., F. Andreux, J. C. Correa, B. Volkoff, and C. C. Cerri, Changes in organic matter in an Oxisol from central Amazon forest during eight years as pasture determined by ${ }^{13} \mathrm{C}$ isotopic Composition, in Diversity of Environmental Biogeochemistry, pp. 398-405. Elsevier. New York. 1991.

Clapperton, C., Quaternary Geology of South Ȧmerica, Eisevier Science, New York, 1993.

Davidson, E. A., and I. L. Ackerman, Changes in soil carbon inventory following cultivation of previously untilled soil, Biogeochemistry, 20, 161-194, 1993.

Davidson, E. A., and S. E. Trumbore, Production of $\mathrm{CO}_{2}$ in deep soils of the eastern Amazon, Tellus, in press, 1995.

Desjardins, T., F. Andreux, B. Volkoff, and C. C. Cerri, Organic carbon and $13 \mathrm{C}$ contents in soils and soil size-fractions, and their changes due to deforestation and pasture installation in eastern Amazonia, Geoderma, 61, 103-118, 1994.

Detweiler, R. P., Land use change and the global carbon cycle: The role of tropical soils, Biogeochemistry, 2, 67-93, 1986. 
Dörr, H., and K. O. Münnich, Annual variations of the ${ }^{14} \mathrm{C}$ content of soil $\mathrm{CO}_{2}$, Radiocarbon, 28, 338-345, 1986.

Eden, M. J., P. A. Furley, D. F. M. McGregor, W. Milliken, and J. A. Ratter, Effect of forest clearance and burning on soil properties in northern Roraima, Brazil, For.Ecol. Manag.,38, 283-290, 1991.

Fan, S.-M., S. C. Wofsy, P. S. Bakwin, D. J. Jacob, and D. R. Fitzjarrald, Atmosphere-biosphere exchange of $\mathrm{CO}_{2}$ and $\mathrm{O}_{3}$ in the central Amazon forest, J. Geophys. Res., 95, 16,851-16, 864, 1990.

Fisher, M. J., I. M. Rao, M. A. Ayarza, C. E. Lascano, J. I. Sanz, R. J. Thomas, and R. R. Vera, Carbon storage by introduced deep-rooted grasses in the South American savannas, Nature, 371, 236-238, 1994.

Hecht, S., Development and politics: capital accumulation and the livestock sector in eastern Amazonia, World Devel., 13, 633-684, 1985.

Hseih, Y. P., Pool size and mean age of stable soil organic carbon in cropland, Soil Sci. Soc. Am. J., 56, 460-464, 1992.

Jenny, H., S. P. Gessel, and F. T. Bingham, Comparative study of decomposition rates of organic matter in temperate and tropical regions, Soil Sci. 67, 419-432, 1949.

Klinge, H., and W. A. Rodriguez, Litter production in an area of Amazonian terra firme forest, 1, Litter-fall, organic carbon, and total nitrogen contents of litter, Amazoniana, l, 287-302, 1968.

Lugo, A. E., and S. Brown, Management of tropical soils as sinks or sources of atmospheric carbon, Plant Soil, 149, 27-41, 1993.

Luizão, F. J., and H. O. R. Schubart, Litter production and decomposition in a terra firme forest of Central Amazonia, Experientia, 43(3), 259$265,1987$.

Manning, M. R., and W. H. Melhuish, Atmospheric $\Delta^{14} \mathrm{C}$ record from Wellington, in Trends '93: A compendium of data on Global Change, edited by T. A. Bowden et al., pp. 193-201, Rep. 65 Carbon Dioxide Anal. Inf. Center, Oak Ridge Nat. Lab., Oak Ridge, Tenn., 1994.

Mattos, M. M., and C. Uhl, Economic and ecological perspectives on ranching in the eastern Amazon, World Dev., 22, 145-158, 1994.

Millington, R. J., and R. C. Shearer, Diffusion in aggregated porous media, Soil Sci., 3, 372-378, 1971.

Mook, W., and J. Jonsma, Measurement of the $\mathrm{N}_{2} \mathrm{O}$ correction for ${ }^{13} \mathrm{C} /{ }^{12} \mathrm{C}$ ratios of atmospheric $\mathrm{CO}_{2}$ by removal of $\mathrm{N}_{2} \mathrm{O}$, Tellus Ser. $B, 39,96-99,1987$.

Nadelhoffer, K. J., and J. W. Raich, Fine root production estimates and belowground carbon allocation in forest ecosystems, Ecology, 73, 1137-1147, 1992.

Nepstad, D. C., C. Uhl, and E. A. S. Serrao, Recuperation of a degraded Amazonian landscape: forest recovery and agricultural restoration, Ambio, 20, 248-255, 1991.

Nepstad, D. C., C. R. de Carvalho, E. A. Davidson, P. H. Jipp, P. A Lefebvre, G. H. Negreiros, E. D. da Silva, T. Stone, S. Trumbore, and $S$. Vieira, The role of deep roots in the hydrological and carbon cycles of Amazonian forests and pastures, Nature, 372, 666-669, 1994.

Nepstad, D. C., P. Jipp, P. Moutinho, G. Negreiros, and S. Vieira, Forest recovery following pasture abandonment in Amazonia: canopy seasonality, fire resistance, and ants, in Evaluating and Monitoring the Health of Large-Scale Ecosystems, edited by D. J. Rapport, C. L. Gaudet, and P. Calow, pp. 333-341, Springer-Verlag, New York, 1995.

Parton, W. J., D. S. Schimel, C. V. Cole and D. S. Ojima, Analysis of factors controlling soil organic matter levels in Great Plains grasslands, Soil Sci. Soc. Am. J., S1, 1173-1179, 1987.

Post, W. M., P. Emanuel, P. J. Zinke, and A. G. Stangenberger, Soil carbon pools and world life zones, Nature, 298, 156-159, 1982.

Potter, C. S., J. T. Randerson, C. B. Field, P. A. Matson, P. M. Vitousek, H. A. Mooney, and S. Klooster, Terrestrial ecosystem production: A process model based on global satellite and surface data, Global Biogeochem.Cycles, 7, 811-842, 1993.

Raich, J. W., and K. J. Nadelhoffer, Belowground allocation in forest ecosystems - Global trends, Ecology, 70, 1346-1354, 1989.

Raich, J. W., and W. H. Schlesinger, The global carbon dioxide flux in soil respiration and its relationship to vegetation and climate, Tellus Ser. $B, 44,81-99,1992$.
Richter, D. D., and L. I. Babbar, Soil diversity in the tropics, Adv. Ecol. Res., 21, 315-389, 1991.

Schimel, D. S., B. H. Braswell, E. A. Holland, R. McKeown, D. S. Ojima, T. H. Painter, W. J. Parton, and A. R. Townsend, Climatic, edaphic and biotic controls over storage and turnover of carbon in soils, Global Biogeochem. Cycles, 8, 279-293, 1994.

Schlesinger, W. H., Carbon balance in terrestrial detritus, Ann. Rev. of Ecol.Syst. 8, 51-81, 1977.

Serrao, E. A., and J. M. Toledo, Sustaining pasture-based production systems in the humid tropics, in Development or Destruction: the conversion of tropical forest to pasture in latin America, S.B. Hecht. ed., Westview press, Boulder, Colorado, 1988.

Skole, D., and C. Tucker, Tropical deforestation and habitat fragmentation in the Amazon - Satellite data from 1978 to 1988 , Science, 261, 1905-1910, 1993.

Sombroek, W. G., Amazon Soils, Cent. for Agric. Publ. and Doc., Wageningen, Netherlands, 1966.

Sombroek, W. G., F. O. Nachtergaele, and A. Hebel, Amounts, dynamics and sequestering of carbon in tropical and subtropical soils, Ambio, 22, 417-426, 1993.

Southon, J. R., et al, Progress in AMS measurements at the LLNL spectrometer, Radiocarbon, 34, 473-477, 1992.

Stuiver, M., and H. Polach, Reporting of ${ }^{14} \mathrm{C}$ data, Radiocarbon, $19,355-$ 363, 1977.

Topp, G. C., and J. L. Davis, Measurement of soil water content using time-domain reflectometry (TDR): A field evaluation, Soil Sci. Soc. Am. J., 49, 19-24, 1985.

Townsend, A. R., The effect of temperature and land use on soil carbon storage in forest ecosystems of Hawaii, Ph.D. thesis, Stanford University, Stanford, Calif., 1993.

Townsend, A. R., P. M. Vitousek, and E. A. Holland, Tropical soils could dominate the short-term carbon cycle feedbacks to increased global temperatures, Clim. Change, 22(4), 293-303, 1992.

Townsend, A. R., P. M. Vitousek, and S. E. Trumbore, Soil organic matter dynamics along gradients of temperature and land-use on the island of Hawai' i, Ecology, 76, 721-733, 1995.

Trumbore, S. E., Comparison of carbon dynamics in two soils using measurements of radiocarbon in pre-and post-bomb soils, Global Biogeochem. Cycles, 7, 275-290, 1993.

Trumbore, S. E., S. Schiff, R. Aravena, R. Elgood, and P. Dillon, Sources of dissolved organic carbon in surface and groundwaters in a forested catchment: the role of soils, Radiocarbon, 34, 626-635, 1992.

Veldkamp, E., Soil organic carbon dynamics in pastures established after deforestation in the humid tropics of Costa Rica, Ph.D. thesis, Wageningen, Cent. for Agric. Publ. and Doc., Wageningen, Netherlands, 1993.

Veldkamp, E., Organic carbon turnover in 3 tropical soils under pasture after deforestation, Soil Sci. Soc. Amer. Jourmal, 58, 175-180, 1994.

Vitorello, V. A., C. C. Cerri, F. Andreaux, C. Feller, and R. L. Victória, Organic matter and natural carbon-13 distribution in forested and cultivated oxisols, Soil Sci. Soc. Am J., 53, 773-778, 1989.

Vogel, J. S., A rapid method for preparation of biomedical targets for AMS, Radiocarbon, 34, 344-350, 1992.

Vogel, J. S., J. R. Southon, D. E. Nelson, and T. A. Brown, Performance of catalytically condensed carbon for use in AMS, Nucl. Instrum Methods Phy. Res. Se ct B, 5, 284-293, 1984.

P. Barbosa de Camargo and L. A. Martinelli, Centro de Energia Nuclear na Agricultura, Av. Centenario 303, Piracicaba, SP, 13416000 Brazil. (email pcamargo@pira.cena.usp.br, lamartin@pintado.ciagri.usp.br) E. A. Davidson and D. C. Nepstad, Woods Hole Research Center, P.O. Box 296, Woods Hole MA 02543. (email: eadwhrc@mcimail.com; dcnwhrc@mcimail.com)

S. E. Trumbore, Department of Earth System Science, University of California, Irvine, CA 92717-3100. (email:setrumbo@uci.edu)

(Received Januray 11, 1995; revised June 14, 1995; accepted July 14, 1995). 